\title{
NOTICIA DE «PLANA DEL LUNES», SUPLEMENTO LITERARIO DE EL GLOBO (1897-1898)
}

\author{
Cecilio Alonso \\ cecilnico@msn.com \\ U.N.E.D., C.A. «Francisco Tomás y Valiente» \\ Alzira-Valencia
}

\begin{abstract}
Resumen
«Plana del Lunes» (1897-1898) fue suplemento literario del diario madrileño El Globo dirigido por José Francos Rodríguez. Se ofrece aquí una aproximación de conjunto a su contexto, una cuantificación analítica de algunos aspectos del contenido, el esbozo de su evolución, un índice de autores y un resumen de la aportación de los más destacados: entre otros Francisco Navarro Ledesma, Jacinto Benavente, Andrés Ovejero, Manuel Bueno, Pío Baroja y Bernardo González de Candamo. Este último contribuyó a publicar un texto de Henri Cornuty sobre Mallarmé, indicio del giro simbolista del suplemento tras la guerra con Estados Unidos.
\end{abstract}

Palabras clave: Suplementos literarios, El Globo, índice de autores y títulos, Francos Rodríguez, Navarro Ledesma, Benavente, Andrés Ovejero, Manuel Bueno, Bernardo G. de Candamo, Pío Baroja, Henri Cornuty, Mallarmé

\begin{abstract}
Between 1897 and 1898 «Plana del Lunes» was the literary supplement of the newspaper El Globo from Madrid, which was directed by José Francos Rodríguez. We are hereby presenting a comprehensive approach to its context, an analytical account of some aspects of its contents, the outline of its evolution, index of authors and a summary of the contribution of its most relevant contributors, including Francisco Navarro Ledesma, Jacinto Benavente, Andrés Ovejero, Manuel Bueno, Pío Baroja and Bernardo González de Candamo. The latter contributed to the publication of a text by Henri Cornuty about Mallarmé, a sign of the symbolist twist taken by the supplement after the war against the United States.
\end{abstract}

Anales, 26, 2014, pp. 43-80

DOI: 10.14198/ALEUA.2014.26.02 
Keywords: literary supplements, El Globo, index of authors and titles, Francos Rodríguez, Navarro Ledesma, Benavente, Andrés Ovejero, Manuel Bueno, Bernardo G. de Candamo, Pío Baroja, Henri Cornuty, Stéphane Mallarmé

\section{El medio y sus redactores}

Fundado en 1975, El Globo había conservado su pedigrí castelarista de republicanismo moderado en progresiva acomodación al canovismo, bajo la propiedad y dirección de Eleuterio Maisonnave (muerto en 1890). Al político alicantino le sucedió su redactor-jefe, Alfredo Vicenti con quien acabó rompiendo Castelar en 1893 cuando, tras la recuperación del sufragio universal, sin opciones de acceder al poder, se sintió agotado ante la presión de los prohombres de su partido que clamaban por la incorporación formal del posibilismo al campo dinástico (Alberola: 1950: 157-160). En plena crisis abierta por el naufragio del crucero «Reina Regente» (marzo de 1895), El Globo sufrió el asalto de un numeroso grupo de militares y paisanos que, so pretexto de defender el honor del ejército afectado por un artículo de Robustiano Sánchez Marroquín, exigían el restablecimiento de la jurisdicción militar para los delitos de opinión. Aquellos sucesos -repetidos en la redacción de El Resumen- precipitaron la crisis del gobierno de Sagasta y acentuaron el fraccionamiento liberal en la oposición, alguno de cuyos líderes emergentes -siguiendo el ejemplo de Canalejas, que se les había anticipado al fundar El Heraldo de Madrid en 1890- trataron de hacerse con órganos propios desde los que defender sus intereses políticos sectoriales en las delicadas circunstancias generadas por el rebrote independentista en Cuba.

Tal fue el caso de Álvaro Figueroa y Torres (1863-1950), conde de Romanones, que, en febrero de 1896, adquiría la propiedad de El Globo ${ }^{1}$ y confiaba su dirección a José Francos Rodríguez (1862-1931). Éste, médico y periodista de procedencia republicana, se había iniciado en la redacción radical de El

1. Pese a sus primeros pasos como politólogo positivista (El régimen parlamentario o la política de gabinete, 1886 y Biología de los partidos políticos, 1892) se dijo del pragmático Romanones que había llegado al poder «desnudo de historia y de obra intelectual, sin fama y sin partido... para satisfacer su vanidad» (Barriobero, 1916: 280-281). En 1902, cuando ya había sido alcalde de Madrid y ministro de Instrucción pública, fundó otro periódico de nuevo cuño -Diario Universal- traspasando El Globo a Emilio Ríus, quien propició una efímera fase de brillantez literaria (1902-1903) de la mano de Pío Baroja, Martínez Ruiz, López Pinillos y otros jóvenes intelectuales, sin conseguir evitar la decadencia de la publicación. En 1913 su tirada había descendido a ocho mil ejemplares (Desvois, 1977: 30). 


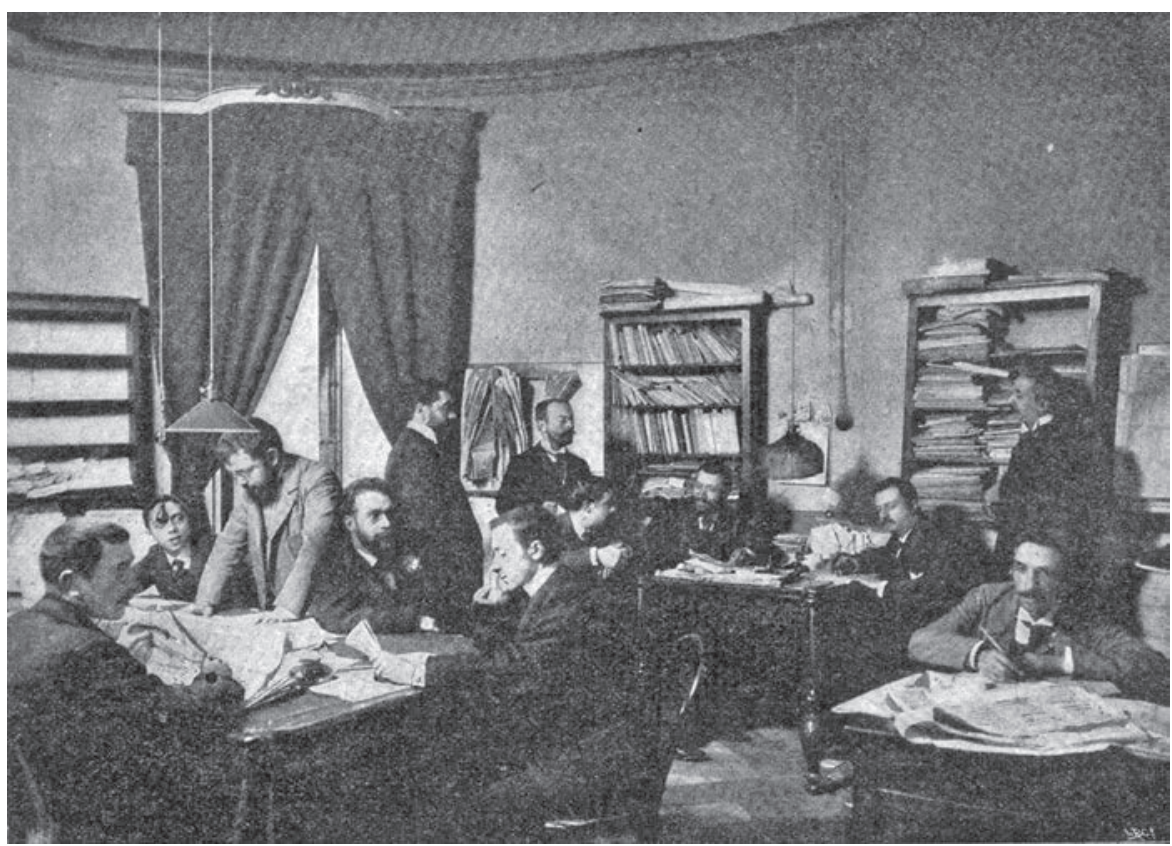

De izquierda a derecha: José V. Alcañiz, E. Zamora, Francisco Navarro Ledesma (de pie), Andrés Ovejero, Leandro Niño (de pie), Juan José Daza de Campos, Pérez Esteban (de pie), Manuel Castro y Tiedra, José Francos Rodríguez, Francisco Serrano de la Pedrosa, Santiago Oria y Calixto Ballesteros (de pie). [Blanco y Negro, 283, 3 de octubre 1896. Fot. de M. Franzen] [Colección del autor]

País y había proclamado su fe en la ciencia «redentora de la argolla del verdugo» en La novela de Urbesierva (1887) colección de relatos en los que predominaba la nota anticlerical. En pleno auge de la Unión Republicana (1893) dirigió el diario salmeronista La Justicia a propuesta de Ruiz Contreras (1946: 31) quien alardeaba de haberle asignado una mensualidad de 76 pesetas por sus colaboraciones en el semanario La caricatura donde firmaba con el seudónimo Juan Palomo². Pío Baroja (1951: 238-239; 1945: 322, 327), que lo trató primero en La Justicia y más tarde en El Globo, lo juzgó con despego al recordar que se tomaba la literatura a broma y que se las echaba de sentir un gran

2. Ruiz Contreras conservaba buena relación con el diario de Francos Rodríguez a juzgar por la elogiosa reseña sin firma dedicada en la «Plana del Lunes» («Índice de libros», 29-3-1897) a su librito Tres moradas donde describía sus visitas a las casas de Menéndez Pelayo, Pereda y Galdós.

Anales, 26, 2014, pp. 43-80 
misticismo republicano. Sin embargo, este entusiasmo se extinguió pronto. Concejal republicano en 1895, su brusco compromiso con Romanones fue el primer indicio de un desplazamiento ideológico hacia el campo monárquico que, con el tiempo, lo llevó a acomodarse en el centro del espectro político liberal-demócrata, tras ejercer la dirección del Heraldo (1902-1906). Obtuvo reconocimientos institucionales, desempeñó altos cargos del poder ejecutivo y llegó a académico de la lengua en 1924.

Fue Francos Rodríguez quien tomó la decisión de publicar en El Globo un suplemento semanal que -siguiendo los modelos establecidos por El Imparcial, La Época o El Liberal- concentrara los contenidos literarios y culturales dispersos irregularmente durante la semana. Se tituló «Plana del Lunes» y se sostuvo con pocas intermitencias desde marzo de 1897 a diciembre de 1898, coincidiendo con el periodo álgido de las guerras coloniales. El Globo había gozado de una envidiable posición en la prensa madrileña durante el decenio anterior, cuando compartía con El Liberal el tercer puesto en difusión, tras La Correspondencia y El Imparcial (Castillo, 1975: 193). Pero sus circunstancias financieras en 1897 no permitían dispendios extraordinarios a juzgar por las firmas de los colaboradores, en buena parte oscuros o muy jóvenes que, presumiblemente, cedían sus plumas a título gratuito.

La producción de la «Plana» en el aspecto literario recayó sobre los hombros de redactores y colaboradores fijos del diario, entre los que descollaba el toledano Francisco Navarro Ledesma (1869-1905), proteico escritor llamado a mayores empresas pero malogrado por su muerte prematura. Funcionario del Cuerpo facultativo de Archiveros, Bibliotecarios y Anticuarios desde 1890, cuyo sueldo de mil quinientas pesetas anuales era insuficiente para afrontar la delicada situación económica de su familia, se trasladó a Madrid donde se multiplicó en diversas actividades periodísticas y docentes que mejoraron sus ingresos. De ahí su presencia intensiva en el semanario ilustrado Apuntes de Silverio de la Torre, en Gedeón ${ }^{3}$ junto a su amigo el redactor de Blanco y Negro Luis Royo Villanova, y en El Globo, introducido por Romanones, en enero de 1896, para que se encargara de varias secciones con el estipendio mensual de treinta duros. Por las mismas fechas comenzó a colaborar en El Imparcial y en otros periódicos alcanzando -según propia confesión- rendimientos próximos a las mil pesetas mensuales en abril de 1896 (Zulueta, 1969: 43-47,

3. Semanario que comenzó a publicarse a fines de 1895 dirigido por el dibujante Joaquín Moya y redactado por Navarro Ledesma, Royo Villanova (1866-1900) y José Roure (1865-1909). 
125-134). A mediados de 1898 obtuvo por oposición la cátedra de Preceptiva Literaria del Instituto de San Isidro y desde entonces su actividad en la «Plana del Lunes» se redujo a un par de comentarios circunstanciales motivados por la recepción de Fernanflor en la Academia (14 de noviembre) y por la muerte de su íntimo amigo Ganivet ( 5 de diciembre), aunque siguió publicando en el diario entre semana reseñas y secciones fijas como «Entresijos»o «En tal día como hoy», esta última con el seudónimo de Calínez, el más famoso personaje de Gedeón. Recordaba Francos Rodríguez (1930: 200-201) que entre el grupo de jóvenes «sobresalientes» reunidos en la redacción de El Globo, Navarro Ledesma destacaba por su talento y por su conocimiento «de las hermosuras del idioma».

En la redacción se hallaba también un versátil Mínimo, seudónimo opaco que bien pudiera ser de uso colectivo, por más que lo utilizara en Revista Nueva poco después Ruiz Contreras (1946: 269). Mínimo rubricó «Instantáneas» de candente actualidad, versos humorísticos, pies de grabados y algunos artículos que traslucen notable conocimiento de literatos, artistas y filósofos extranjeros, como el titulado «El individualismo literario» (27-9-1897). Otro joven redactor con regular actividad en el suplemento, al que aportó crónicas y semblanzas literarias, fue Andrés Ovejero Bustamante (1871-1954) futuro catedrático de Literatura en la Universidad de Madrid que había de evolucionar más tarde hacia el socialismo ${ }^{4}$. Presencia similar tuvo el también médico murciano Francisco Serrano de la Pedrosa (c. 1855-1926) -sainetista, colaborador de Madrid Cómico y director literario de La Caricatura (18921893)-, autor de cuentos, crónicas de costumbres y análisis educativos en la «Plana». Entre noviembre de 1897 y febrero de 1898 aparecieron las crónicas literarias y sociológicas más incisivas del joven Manuel Bueno (1874-1936), que alternaba su nombre con el seudónimo Lorena. Su aportación doctrinal y artística fue primordial para la introducción controlada de conceptos estéticos modernistas en el suplemento. De su misma edad, José Rocamora, Tersites, (1874-1936) salteaba cuentos, crónicas, divulgación científica y otros modestos menesteres como el de comentar fotograbados. El director, Francos Rodríguez firmó cuentos, un poema y otros asuntos de actualidad. En menor escala se hicieron notar otros redactores: Calixto Ballesteros -habitual de certámenes poéticos y juegos florales-, el granadino Manuel Castro y Tiedra,

4. Ovejero interrumpió sus colaboraciones en la «Plana» a fines de 1897 al marchar a Puerto Rico, de donde regresó repatriado en el vapor Montevideo, un año después («Andrés Ovejero», El Globo, 5-11-1898, p. 1). Aquella experiencia le inspiró una serie de doce sonetos testimoniales titulados «El año terrible» (El Globo, 31-12-1898). 
Barón de Sttoff, cronista de salones que acompañó después como hombre de confianza a Francos en el Heraldo, y David Miranda que firmó una sola vez. Copiosa fue la colaboración del corresponsal de El Globo en Segovia, Silverio de Ochoa, que contribuyó con una veintena de cuentos. En cambio se redujo a cinco firmas la presencia del corresponsal en la capital francesa, A. Sea, que rubricaba habitualmente entre semana la sección «Notas parisienses». Próximo a la redacción, pero sin integrarse en ella, estuvo el artillero valenciano radicado en San Sebastián, Vicente Sanchís Guillén, Miss Teriosa (1849-1907). Al agravarse la situación colonial, dejó de lado cuentos y crónicas literarias para centrarse en aspectos militares.

Cronológicamente la pirámide de edad de los redactores y colaboradores aparece invertida, lo que podría abonar la sospecha de que el suplemento estaba en manos de veteranos históricos del Sexenio. Sin embargo el peso de su orientación semanal recaía en otros más jóvenes, formados intelectualmente en la Restauración o en la Regencia. Sobre una muestra aleatoria de sesenta firmas suficientemente documentadas, un $45 \%$ de los firmantes habrían nacido antes de 1860 y frisarían los cincuenta y tantos años de edad. Los nacidos en el decenio 1861-1870 serían poco más del 30\%, y apenas un 12\% los venidos al mundo a partir de 1871, que en 1898 contaban entre 17 y 27 años. De los primeros fueron los más activos Sanchís y Serrano de la Pedrosa, en un tramo de edad madura en el que también figuraban Concepción Gimeno, autora de didascalias femeninas, Manuel Ossorio Bernard, Rafael Salillas, Eusebio Blasco y los poetas Salvador Rueda, su amigo Ricardo Cano y Fernández Grilo. En el segundo escalón, entre los treinta y los cuarenta años, se integraban las firmas fuertes de la «Plana», Francos Rodríguez y Navarro Ledesma junto a Silverio de Ochoa, el granadino Nicolás María López -luego colaborador de La Vida Literaria- y, ocasionalmente, Sofía Casanova, López Silva o Jacinto Benavente. Por último, la «gente moza» -definida por Navarro Ledesma en una memorable serie de artículos en «Los Lunes de El Imparcial» a fines de 1898- la encabezaban los redactores Ovejero, Bueno y Rocamora con Pío Baroja, incorporado al suplemento en su la última fase, Manuel Calvín y Redondo que dejó una interesante serie de cuentos para eclipsarse después, la educadora Magdalena de Santiago y los jovencísimos Martínez Sierra, el zaragozano Antonio Mompeón Motos y el asturiano Bernardo González de Candamo, nacidos en 1881. 


\section{La «Plana del Lunes» en su contexto periodístico}

Antes de concentrarlos en el suplemento, entre los diseminados contenidos literarios de El Globo predominaban cuentos, crónicas y correspondencias europeas. La crítica de libros era irregular. En el primer número del año, Navarro Ledesma, había ofrecido una panorámica sombría de la producción literaria española en 1896. En su resumen, el magro estado de la lírica en 1896 lo llevaba a observar mayor interés en la poesía catalana de Verdaguer, reciente autor de Flors del calvari y de Jesús Infant, que en los últimos libros de Rodríguez Marín, López Silva o Federico Balart. En narrativa, la inactividad de Galdós la compensaban el ingenio de Valera (Juanita la Larga) y el vigor narrativo de Pereda (Pachín González) mientras -a su juicio- habían pasado desapercibidas para la crítica Memorias de un solterón de Pardo Bazán y Los majos de Cádiz de Palacio Valdés. Días después, Navarro en su sección miscelánea "Libre plática», donde ensayaba una especie de particular causerie, apelaba a la sombra pesimista de Larra para arremeter en abstracto contra la censura que acechaba al periodista en aquel tiempo de guerras (4-1-1897). En la misma sección juzgó con amable severidad al autor de Paz en la guerra (181-1897) a quien reprochaba el no dar con el lenguaje adecuado para expresar rectamente la profundidad de su pensamiento, y respondió fogosamente a las críticas de Clarín, tildándolo de «soberbio y mal educado» (21-2-1897), lo que derivó en polémica al disentir el entonces redactor del Heraldo Federico Urrecha. El 8 de febrero, Navarro introducía una extensa información a doble página sobre el ingreso de Galdós en la Academia, y quince días después hacía lo propio en la recepción de Pereda. Con menor asiduidad, se hacían notar las firmas de Andrés Ovejero tratando asuntos diversos; la de Castelar sobre política internacional; algún cuento de José Zahonero -autor incluido en la nómina de «gente nueva» por Luis París (1889)-; alguna «dolora» inédita; informaciones musicales de M. Manrique de Lara y una sección de «Hojas sueltas» con firmas esporádicas de autores europeos -Adolfo Ribaux, Hugues Le Roux, Armand Silvestre, seguramente de agencia. El corresponsal en París, A. Sea, publicó una semblanza de Verlaine (18-1-1897) en el primer aniversario de su muerte que incluía un informe exclusivo de Gabriel Echaupre, amigo del poeta. Folletines compaginados en los faldones del periódico formaban la «Biblioteca de El Globo» donde alternaban novelas de género -El collar de la muerta de Henri Demesse y Donde conduce el amor de Léopold Stapleaux-con documentos generados por la Escuela de Estudios Superiores del Ateneo de Madrid con textos de Pedrell, del arqueólogo Celestino Acevedo, de Jenaro Alas y otros. Completaban la dispersa información cultural índices bibliográficos, reseñas ocasionales y avances fragmentarios de libros recientes en los 
que, a veces, se trasluce el móvil de la deferencia amistosa y el compromiso clientelar con amigos y correligionarios ${ }^{5}$.

Materiales de esta especie se centralizaron desde el 1 de marzo, previo aviso pero sin explicación programática, en la tercera página del diario, compuesta a cinco columnas de unos treinta mil caracteres, equivalente a un cuadernillo de unas 19 páginas, inferior al volumen de lectura que proporcionaban por las mismas fechas los suplementos de El Liberal, que lo duplicaba, o de El Imparcial que daba una tercera parte más.

Seña tipográfica identificadora desde el nacimiento del periódico había sido la inserción de imágenes. En esta tradición la «Plana» se articulaba en torno a un fotograbado, no siempre de actualidad -paisaje, retrato, pintura o motivo artístico...- que prestaba cohesión visual al conjunto tipográfico, acompañado de un pie explicativo-«Nuestro grabado»-al modo de las «Ilustraciones» decimonónicas, frecuentemente firmado por redactores. Contra lo que era habitual en las imágenes que, a mediados del decenio, se insertaban en «Los Lunes de El Imparcial» subordinadas a los textos con objeto de completarlos, en El Globo se llegó a defender que la imagen no era subsidiaria del texto, sino al revés. El comentario verbal servía para superar las insuficiencias de aquélla y prevalecía sobre la representación gráfica porque «la impresión puramente plástica de tipos y paisajes» no daba idea moral de las costumbres, cuyo trazado requería reflexión e instrumentos más adecuados para expresar su complejidad (Mínimo, «Un mercado en Murcia», 13-12-1897). En ciertos casos estos comentarios mostraban una intencionada extrapolación transversal: un fotograbado del cuadro La Floralia de un pintor de oficio como el malagueño Antonio Reina Menescau, medalla de bronce en la exposición de Bellas Artes de 1887, daba pie a N. [avarro] para menospreciar a los Goncourt, al feísmo naturalista y al socialista Jaurès a quien imaginaba cantando «los brutales y roncos acentos de la Carmagnole» (29-11-1897). En otro momento, tras la catástrofe naval de Santiago de Cuba, durante dos semanas consecutivas (1 y 8-8-1898) se ofrecieron grabados relativos al bombardeo y entrada de las tropas británicas en Alejandría (1882), considerando increíble que tales métodos no disuadieran a los pueblos de buscar el amparo anglosajón. «Fuerzas muy superiores a éstas -rezaba el segundo pie- se pusieron en juego por

5. Como muestra véase la apostilla a la reseña de «Prosa y versos» (1897) de Fernando Franco Fernández, redactor de El Diario de Albacete y colaborador de «Plana», cuya venta, a peseta ejemplar, destinaba el autor a redimirse del servicio de las armas. "Justo es que sus amigos y compañeros, que le estiman mucho, le auxilien para que logre la consecución de su objeto». 
la nación americana para rendir la plaza de Santiago de Cuba hace poco más de tres semanas».

Si el estado de los asuntos coloniales en 1897 y el inicio de la guerra con Estados Unidos, en abril de 1898, desarbolaron la oferta regular de contenidos literarios en los periódicos madrileños de información general, en cambio reforzaron el papel de semanarios gráficos como Madrid Cómico, Blanco y Negro o Nuevo Mundo, incluidos los satíricos Don Quijote o Gedeón. En los diarios, la información de las guerras ultramarinas y de la grave situación política creada tras la muerte de Cánovas, invadió los espacios destinados normalmente a las secciones culturales. Ni el Heraldo ni La Correspondencia publicaban hojas específicas. $L a$ Época, diario conservador de antigua tradición literaria reducía a la mínima expresión sus esmerados suplementos ilustrados (cuatro números entre marzo de 1897 y enero de $1898^{6}$ ). Al iniciarse la publicación de «Plana del Lunes» sólo El Imparcial sostenía su hoja semanal. Poco después (9 de mayo) se sumaba el último diseño suplementario de Isidoro Fernández Flórez en El Liberal, «Nuestros Domingos», con colaboraciones del propio Fernanflor, Valera, Núñez de Arce, Pardo Bazán, Benot, Echegaray, Eusebio Blasco, García Ladevese, Manuel Reina, Vital Aza, Octavio Picón, Oller, Pérez González, Blasco Ibáñez y Ricardo de la Vega, entre otros. Pero no alcanzó a completar un año de vida y desapareció el 20 de marzo de 1898 al declararse la guerra hispano-yanqui (Alonso, 2002: 40-44 y 88-103). Incluso la incombustible cabecera de «Los Lunes de El Imparcial» se eclipsó por el mismo motivo durante más de un semestre, al tiempo que se producía una drástica reducción de los contenidos literarios del periódico. En tal contexto, «Plana del Lunes» fue un caso de máxima resistencia formal con sólo nueve ausencias a lo largo de ochenta y seis semanas, aunque suspendió puntualmente la salida de un par de números y hubo de reforzar las claves patrióticas en los instantes de mayor tensión. Una de las entregas de la serie titulada «Nuestro adversario» (18 de abril), llegó a ocupar con un solo artículo toda la «plana». En ella Vicente Sanchís exponía sus recuerdos como agregado militar en la embajada española en los Estados Unidos y analizaba sus poderosas fuerzas armadas, mostrándose decepcionado por el giro belicista de la democracia norteamericana:

6. 21-3-97, textos de Rodrigo Soriano, Zeda (Fernández Villegas), José Herrero y Mascarilla (Alfredo Escobar); 16-4-97, dedicado a la Semana Santa; 27-6-97, textos de Pereda, Patrocinio de Biedma, Juan Catalina, Zeda y Rafael Altamira que publicó su cuento «Despedida» fechado en 1892; 6-1-98, lujoso monográfico dedicado al cincuentenario del periódico con testimonios de los históricos Fernando Cos-Gayón, Carlos Navarro Rodrigo, Joaquín Maldonado Macanaz, Kasabal y otros. 
«Si la guerra estalla, si la gran iniquidad se realiza, si triunfan los mercaderes de conciencias arrastrando a la masa indiferente hacia el abismo de una lucha desesperada, el país que blasonaba de figurar en cabeza de las tablas de la ley de la civilización y del progreso, habrá iniciado la marcha retrógrada en el sentido de la obcecación y la barbarie».

Entre el 1 de marzo de 1897 y el 31 diciembre de 1898, las nueve suspensiones de «Plana del Lunes» obedecieron a elecciones, a festividades locales o al mentado impacto informativo de la guerra. Salieron en total ochenta y siete suplementos (cuarenta en 1897 y cuarenta y siete en 1898). Durante el mismo tiempo El Liberal sacó el suyo durante cuarenta y tres domingos, y El Imparcial «Los Lunes» durante cincuenta y seis semanas. Pero, sin mediar explicación, El Globo suprimió la «Plana» al comenzar 1899, mientras que «Los Lunes de El Imparcial» se consolidaba como suplemento literario de referencia hasta 1933 (Alonso, 2006).

Respecto a la cuantificación de contenidos, prescindiendo de reseñas anónimas y de otros sueltos, el nomenclátor del suplemento supera los 140 autores, de los que un 9\% son extranjeros (franceses, italianos, griegos, daneses, norteamericanos y rusos), y tan sólo un $2 \%$ clásicos españoles y latinos. Los artículos firmados sobrepasan tres centenares, los no firmados ascienden a setenta y cinco:

Cuadro I. Distribución cuantitativa de textos

\begin{tabular}{|c|c|c|c|c|c|}
\hline & 1897 & $\begin{array}{c}\text { media de } \\
\text { artículos } \\
\text { por } n .^{\circ}\end{array}$ & 1898 & $\begin{array}{c}\text { media de } \\
\text { artículos } \\
\text { por } n .^{\circ}\end{array}$ & total \\
\hline $\begin{array}{l}\text { a) } \\
\text { Artículos firmados } \\
\text { Con seudónimo } \\
\text { Con iniciales } \\
\text { total }\end{array}$ & $\begin{array}{r}153 \\
17 \\
13 \\
183\end{array}$ & {$[4,06]$} & $\begin{array}{r}159 \\
16 \\
10 \\
185\end{array}$ & {$[3,08]$} & $\begin{array}{r}312 \\
33 \\
23 \\
368\end{array}$ \\
\hline $\begin{array}{l}\text { b) } \\
\text { Artículos no firmados } \\
\text { Publicidad } \\
\text { Espectáculos. Cartelera } \\
\text { Pies de grabados } \\
\text { Totales }(\mathbf{a}+\mathbf{b})\end{array}$ & $\begin{array}{r}12 \\
2 \\
1 \\
10 \\
208\end{array}$ & & $\begin{array}{r}14 \\
0 \\
0 \\
26 \\
225\end{array}$ & & $\begin{array}{r}26 \\
2 \\
1 \\
36 \\
433\end{array}$ \\
\hline
\end{tabular}

Entre el centenar y medio de autores las firmas femeninas sólo representan el 3,3\%. Cinco mujeres, a cuya cabeza estaba, con siete colaboraciones, Concepción Gimeno de Flaquer (1850-1919), veterana publicista curtida en 
múltiples empresas feministas desde una perspectiva conservadora (buenos consejos, modas y salones). Jesusa de Granda, profesora de Normal y miembro de la Asociación de la Prensa de Madrid desde 1895 (Ossorio, 1903: 186) fue autora de cinco colaboraciones (reflexiones morales, pensamientos, prosas literarias). Tres poemas de filiación becqueriana rubricó la actriz dramática Elisa Casas Vigo (colaboradora de La ilustración Española y Americana, La Ilustración Ibérica, Pluma y Lápiz). La conquense Magdalena Santiago Fuentes (1873-1922), entonces maestra en Huesca, publicó en 1898 dos cuentos de interés desigual y una sola vez firmó Sofía Casanova (1861-1958), ya establecida en Polonia, que gozaba de cierta reputación por su libro Poesías (1885) y por su novela El doctor Wolski (1894).

\section{Los géneros}

El Cuadro II trata de resumir información sobre los principales géneros literarios y periodísticos que aparecen, con la estimación -siempre aleatoria- de sus correspondientes despliegues sub-genéricos y de algunas modalidades formales. Como era habitual en este tipo de suplementos el cuento es el género dominante. La particularidad de la «Plana» es que el segundo lugar corresponde al verso lírico, otro género de tradición literaria, desplazando a la crónica, género genuinamente periodístico. Los versificadores superaban la cuarentena pero no fueron precisamente los de mayor reputación -Salvador Rueda, Melchor de Palau o Fernández Grilo- los más pródigos, sino otros más oscuros como Ruperto Bosque, Ricardo Cano, Fernando Franco Fernández o Calixto Ballesteros. Son testimoniales las aportaciones de Ricardo Gil, López Silva, Sofía Casanova, Bueno o Martínez Sierra. Comparativamente, por las mismas fechas en los suplementos de El Imparcial y de El Liberal había menos versos y, en su mayor parte, satíricos, firmados por Javier de Burgos y Vital Aza, en «Los Lunes», y por el propio Aza, Manuel del Palacio, Felipe Pérez González y Ricardo de la Vega, en «Nuestros Domingos». Fernández Vaamonde y Manuel Reina fueron las respectivas excepciones en la tendencia festiva de ambos diarios.

Los fragmentos de reclamo, avances de publicaciones nuevas o en preparación, de hecho no eran colaboraciones exclusivas pero indican las tendencias selectivas de los responsables del suplemento y, sobre todo, evidencian un aprovechamiento del movimiento editorial para ofrecer sin gasto novedades de interés para los lectores. 
Cuadro II. Géneros y formas

\begin{tabular}{|c|c|c|c|}
\hline Géneros y formas & 1897 & 1898 & Total \\
\hline Avance obras nuevas & 15 & 14 & 29 \\
\hline Crítica de arte & 6 & 0 & 6 \\
\hline $\begin{array}{l}\text { Crítica literaria } \\
\text { Reseñas sin firma } \\
\text { En forma epistolar }\end{array}$ & $\begin{array}{r}14 \\
2 \\
0\end{array}$ & $\begin{array}{l}6 \\
5 \\
1\end{array}$ & $\begin{array}{r}20 \\
7 \\
1\end{array}$ \\
\hline $\begin{array}{l}\text { Crónicas } \\
\text { Actualidad } \\
\text { Literarias } \\
\text { Sociales } \\
\text { Correspondencias extranjeras } \\
\text { Actualidad bélica } \\
\text { Artística } \\
\text { Científica/tecnológica } \\
\text { Femenina } \\
\text { Salones } \\
\text { En forma epistolar } \\
\end{array}$ & $\begin{array}{r}29 \\
8 \\
7 \\
4 \\
1 \\
3 \\
4 \\
0 \\
2 \\
1 \\
0 \\
\end{array}$ & $\begin{array}{r}20 \\
3 \\
6 \\
0 \\
3 \\
3 \\
3 \\
1 \\
2 \\
0 \\
3 \\
\end{array}$ & $\begin{array}{r}49 \\
11 \\
13 \\
4 \\
4 \\
6 \\
7 \\
1 \\
4 \\
1 \\
3 \\
\end{array}$ \\
\hline Crítica teatral & 0 & 1 & 1 \\
\hline $\begin{array}{l}\text { Cuentos } \\
\text { Alegóricos } \\
\text { Amatorios } \\
\text { Costumbres sociales } \\
\text { De guerra y repatriación } \\
\text { De artistas } \\
\text { Regeneración } \\
\text { Motivos crepusculares } \\
\text { Asunto rural } \\
\text { Cuento histórico } \\
\text { Cuento folclórico/legendario } \\
\text { Cuento taurino } \\
\text { Cuento fantástico } \\
\text { Cuento navideño } \\
\text { Crónica-cuento } \\
\text { Otros } \\
\text { En forma dialogada } \\
\text { En forma epistolar }\end{array}$ & $\begin{array}{r}38 \\
1 \\
10 \\
4 \\
2 \\
2 \\
0 \\
1 \\
1 \\
3 \\
1 \\
1 \\
0 \\
1 \\
1 \\
11 \\
1 \\
1\end{array}$ & $\begin{array}{r}76 \\
0 \\
20 \\
7 \\
6 \\
4 \\
5 \\
4 \\
3 \\
1 \\
3 \\
1 \\
2 \\
1 \\
2 \\
10 \\
3 \\
4\end{array}$ & $\begin{array}{r}114 \\
1 \\
30 \\
11 \\
8 \\
6 \\
5 \\
5 \\
4 \\
4 \\
4 \\
2 \\
2 \\
2 \\
3 \\
21 \\
4 \\
5\end{array}$ \\
\hline $\begin{array}{l}\text { Divulgación } \\
\text { Histórica } \\
\text { Medicina, higiene, sanidad } \\
\text { Histórico literaria } \\
\text { Científico-técnica } \\
\text { Etnográfica y folclórica } \\
\text { Artístico cultural } \\
\text { Geográfica y geopolítica } \\
\text { Histórico monumental } \\
\text { Histórico religiosa } \\
\text { Historia política } \\
\text { Militar } \\
\end{array}$ & $\begin{array}{r}13 \\
3 \\
3 \\
2 \\
0 \\
1 \\
2 \\
1 \\
0 \\
1 \\
0 \\
0 \\
\end{array}$ & $\begin{array}{r}13 \\
2 \\
3 \\
1 \\
1 \\
1 \\
2 \\
1 \\
0 \\
0 \\
1 \\
1\end{array}$ & $\begin{array}{r}26 \\
5 \\
6 \\
3 \\
1 \\
2 \\
4 \\
2 \\
1 \\
1 \\
1 \\
1\end{array}$ \\
\hline Historia & 3 & 0 & 3 \\
\hline Metaperiodismo & 2 & 3 & 5 \\
\hline Reseñas musicales & 2 & 0 & 2 \\
\hline Textos dramáticos & 3 & 0 & 3 \\
\hline Verso & 39 & 25 & 64 \\
\hline
\end{tabular}

Anales, 26, 2014, pp. 43-80 


\section{Fases de la publicación y aportaciones más significativas}

En «Plana del Lunes» no hubo solemnes declaraciones generacionales, ni manifestaciones orgánicas de carácter intelectual. Tampoco llamativos posicionamientos ante un hecho tan ruidoso como el Proceso de Montjuic, aunque el diario (14-10-1897) no hizo oídos sordos al escrito de los presos barceloneses dirigido al Presidente del Consejo de Ministros. En cambio, como suplemento desarrollado en tiempo de guerra se vio condicionado por sus presiones tanto en la selección de los asuntos como en la urgencia de sus tratamientos ${ }^{7}$, que en los momentos más críticos adoptaron un sesgo abiertamente patriótico.

En un principio, la página se planteó con un criterio culturalista que permitía la propuesta de números monográficos dedicados a los carnavales, a la civilización helénica, a Valera autor de Genio y figura (29-3-1897), a la Semana Santa y a la feria de abril en Sevilla, a la Exposición Nacional de Bellas Artes, a las relaciones entre Francia y Rusia, a la inauguración académica del curso escolar o a la Nochebuena. Pero este diseño fue diluyéndose conforme los apremios de la actualidad imponían nuevas exigencias componiendo números marcados por el acarreo de asuntos varios. En uno de estos números se publicó un cálido texto de Ovejero ("Cristo en el cementerio», 12-1897), aproximación elegiaca a la crisis del yo artístico a partir del suicidio del escultor sevillano Antonio Susillo (diciembre de 1896), atribuido en términos neorrománticos al envilecimiento del ideal y a la decadencia del arte, con sujeción al moderno tono agrisado: «Músicos, pintores, poetas, todos los que sueñan con la perfección sublime de la forma y despiertan para ver las imperfecciones de la estúpida existencia de un mundo monótono y de un cielo gris, acorralados por la indiferencia de las gentes y abrumados por la impasibilidad del cielo».

En el aspecto estético-literario, el desarrollo del suplemento permite periodizar tres fases en las que parecen incubarse diversas tendencias intelectuales a título individual. La primera, la más extensa, entre marzo de 1897 y febrero de 1898, abarca casi un año de aparente normalidad crítica y creativa en clave preferentemente realista con atención predominante a valores literarios consolidados -Valera, Feliu y Codina, Pérez Galdós- y a alguna figura emergente como Ángel Ganivet, de doble actualidad por ser autor de La conquista del Reino de Maya por Pío Cid y por su trágica muerte. Una segunda tendencia durante este primer periodo la encarnó Manuel Bueno quien, desde diciembre de 1897, intentó definir las líneas de la contemporaneidad literaria

7. «Hablemos, pues, aunque deprisa y corriendo como es obligado hacerlo en estos días»se justificaba Navarro Ledesma en «Índice de Libros», 30-5-98. 
bordeando la polémica con Martínez Ruiz y con Unamuno en defensa de la estética dannunziana.

En este periodo no faltaron textos enalteciendo el patriotismo - «Héroes de Fuerte Victoria» de Ovejero (10-5-1897) - donde se apelaba a Spencer, Carlyle, Robert de Sizeranne, López de Palacios o Jerónimo de Urrea, para concluir que las lecciones morales y políticas de la guerra eran superiores a sus aspectos matemáticos, tácticos y estratégicos. Así los supervivientes de aquel lance en Filipinas -Emilio Sánchez Arrojo, capitán, y el teniente médico Felipe Trigo, futuro novelista- aparecían hermosamente heroicos, vistos «con ojos de artista», mitificados y revestidos con «la plasticidad de líneas de los combates antiguos». El propio Trigo, a petición de su colega Francos Rodríguez, había publicado en El Globo, fuera del suplemento, un detallado relato de los hechos sin pretensiones literarias («Fuerte Victoria», 20-4-1897). Pero fue entre marzo y septiembre de 1898 cuando se abrió una fase de convulsión patriótica activa en la que menudearon los paralelismos heroicos de la situación colonial con los tópicos de Numancia y el 2 de mayo, entre estridencias de españolismo herido, invocaciones a los héroes nacionales y belicismo sin ambages contra el «pueblo americano» del que se decía que traicionaba a su historia interviniendo en Cuba, como atestiguan estas ripiosas décimas de Ulpiano Romaña («iViva España!», 25-4-1898): «Basta ya de sufrimiento / y vanas contemplaciones; / templemos los corazones / de Patria en el sentimiento. / De la lucha en el momento / cumplan todos sus deberes, / hombres, niños y mujeres, / demostrando al mundo entero / que no es este pueblo ibero / un pueblo de mercaderes. // Ese pueblo americano, / traición haciendo a su historia, / con avilantez notoria / quiere ejercer de tirano. / Pero ipor Dios! que el hispano / a la pelea se advierte / con tesón y ánimo fuerte / para demostrar a todos / que prefiere de mil modos / a la deshonra, la muerte».

La tercera fase corresponde al otoño de 1898, cuando la derrota estimuló el simbolismo crepuscular y acentuó el cambio de tendencia literaria -fragilidad, regeneracionismo, postración, humanitarismo expiatorio...- con la leve presencia de Pío Baroja y de Candamo, a lo que se sumó el latigazo penitencial que supuso el suicidio de Ganivet motivo del regreso de Navarro Ledesma para diseñar el último monográfico del suplemento, con una extensa antología de su amigo y confidente granadino.

\section{Derroteros críticos. Navarro Ledesma y Benavente}

Como queda dicho la máxima jerarquía crítica durante la primera de las fases mencionadas recayó en Navarro Ledesma que -atento a las novedades editoriales- tuvo oportunidad de reseñar algunos libros relevantes, entre ellos 
Genio y figura, encomiando «la sana y fresca alegría» de Valera con la que -sin ser un escritor popular- se las arreglaba para que el lector nunca dejara de entenderlo «remozando lo envejecido y resucitando mil resortes y formas de enderezar el pensamiento y de construir el lenguaje» (29-3-97). También abordó los tres libros publicados por Galdós en aquel bienio, sin que su metodología divulgativa llegara a explicar convincentemente el último giro espiritualista del autor. Tanto a propósito de Misericordia (17-5-97), como de El Abuelo (6-12-97), el comentarista -galdosiano a toda prueba- se limitaba a insistir en la insuficiencia de las sutilezas intelectuales y del instrumental naturalista -leyes de la herencia o principios fisiológicos puros- para esclarecer una sustancia inefable tan alta y difícil que escapaba a la crítica al uso: la sublimación del amor universal. Así, Misericordia, era «obra de amor, más para sentida que para pensada» y el conflicto de El Abuelo sólo se explicaba por el amor «más alto que todas las previsiones de la ciencia y que todos los prejuicios de la historia o de la tradición». Sirvió de relativo contrapunto el planteamiento incidental de Jacinto Benavente («Notas de un lector», 7-6-97), quien ironizaba sobre los críticos de espera que no se atrevían a pensar por cuenta propia ante la imprevista evolución del estilo galdosiano y aguardaban pronunciamientos de autoridad para ponerse a su sombra. En relación con el esquematismo simbólico historicista con el que había expresado el primer Galdós los conflictos ideológicos del XIX, el bisoño dramaturgo justificaba la ambigüedad del moderno espiritualismo como producto de una «natural y lógica determinación del pensamiento humano» que bajo apariencia de retroceso más bien respondía a un «impulso progresivo». Más allá del misticismo moderno, la diferencia esencial entre las últimas obras de Galdós y las de su primera época venía dada, en su opinión, «mejor que por la influencia de místicas ideales de raíz rusa, por una comprensión más verdadera, más elevada (en el sentido artístico) del alma humana, de la psicología social». Así el realismo de Galdós, lejos de predicar la caridad desde una óptica de clase burguesa, presentaba un cuadro de miserias interiorizadas, iluminado con tan poderosa luz que la miseria misma parecía en él consoladora, con ayuda de una imaginación exenta de «efectos terroríficos», léase residuos naturalistas sin reivindicaciones socialistas.

Navarro Ledesma, atento a la reanudación de los Episodios Nacionales, dedicó a Zumalacárregui (6-6-1898) una reseña divagadora, retórica y muy condicionada por las circunstancias bélicas, donde, tras entonar el non sum dignus por no sentirse a la altura del objeto, evocaba intencionadamente la reserva de «energía nacional» acumulada en los conflictos civiles del XIX: «Previendo luchas con los extraños en el porvenir, no hemos dejado apenas un momento 
de luchar con nosotros mismos; el horno casi no se ha enfriado y el temple no se ha perdido». A mediados de 1898, al comentar el naturalismo idealista e íntimo de Juan Ochoa (Un alma de Dios) y el psicologismo de Gustavo Morales (Más allá) («Índice de libros. Novelas cortas, 30-5-1898), Navarro reflexionaba sobre la coyuntura de la producción novelesca. Estimulada por la fácil lectura de la prensa, se estaba produciendo la pérdida del gusto por los libros extensos de calidad obligados a reflejar una realidad que no podía achicarse ni reducirse. Esto conllevaba que el arte narrativo se estuviera desviando hacia el relato breve y el cuento. La «micrografía» lo iba invadiendo todo en perjuicio de aquella manera «amplia, épica, por excelencia, que se tuvo antaño de entender y de pintar la vida. [...] Al portentoso París, de Zola ya lo han declarado abrumador varios apreciables señoritos de la sección de Annunzios -satirizaba Navarro a costa de la moda sensualista y decadente- y milagro será que no intenten hacer lo mismo con la nueva serie de Episodios nacionales, que emprende el gran Pérez Galdós, con brío juvenil»

Desigual interés ofrecen sus referencias a Ganivet («Un libro raro», 5-497 y la semblanza necrológica que le dedicó el 5-12-98). La primera era un resumen empático de La conquista del Reino de Maya, donde el reseñista, soslayando los aspectos utópicos de la novela se identificaba patrióticamente con Pío Cid, «conquistador romántico e idealista, como conviene a su nación gloriosa y a su gloriosísimo apellido». La segunda, una elegía hagiográfica a las virtudes del amigo íntimo entre la ternura y el desgarro que se añadía al desolador panorama de la derrota ultramarina: «La muerte de Ganivet es una gran desventura, una burla cruel de nuestro sino desdichado, que se nos lleva a los mejores, a los necesarios, a los capaces de remediarlo todo con el soberano poder de sus entendimientos y de sus plumas, que son los que hacen las revoluciones y producen las regeneraciones de los pueblos». El castizo aliento regeneracionista de Navarro Ledesma, reticente con el simbolismo moderno, se dejaba entrever (7-2-1898) al comentar la versión en metro castellano con la que José J. Herrero había sabido mantener «el indefinible encanto de las poesías de Heine» como «en un espejo», ante la que tenían que rendirse incluso los «espíritus fatigados y decadentes de estos tiempos». A esto añadía un oblicuo comentario sobre la escasa disposición de nuestro idioma «a las vaguedades del sentimiento y a dejar indiscernidos y súbitamente anublados los asuntos». Poco antes ya había expresado con ambigüedad paródica su desapego al simbolismo, en su poema «El Cisne» (Blanco y Negro, 20-11-1897): «Por las verdes aguas del estanque / sigue sin rumbo el cisne solitario, / que echa de menos sus brillantes días / y al verse confundido con los patos / en este pavoroso 
desconcierto / que todo lo domina, resignado / tiende el cuello flexible y ondulante, / pronto a exhalar su moribundo canto».

En la «Plana» de El Globo, Navarro se mostraba poco inclinado a respaldar innovaciones literarias radicales, y en sus críticas, generalmente elogiosas, se limitaba a valorar grosso modo el ingenio, la originalidad y la honestidad. Benévola crítica comprensiva pensando en contagiar al público el entusiasmo por sus autores predilectos al tiempo que facilitaba documentación con asequibles referencias comparatistas a escritores extranjeros. Se deja ver que no era la «Plana del Lunes» el lugar preferido por el polígrafo toledano para desarrollar una crítica literaria exigente.

\section{Manuel Bueno y sus ideas literarias en la «Plana del Lunes»}

A Manuel Bueno -crepuscular sin ambages en sus crónicas «Volanderas»- le correspondió hacer de puente conciliador entre lo viejo y lo nuevo en su aportación crítica a la «Plana». Su primera reseña («Crónicas literarias», 1312-1897) ponía en relación El esgaña pobres de Narcís Oller -en la reciente traducción de Rafael Altamira- con la forma de los relatos de Les soirées de Médan y con la profundidad psicológica de Balzac, ponderando la amarga objetividad del catalán en la obligada comparación con el Pereda de La Puchera más tocado «de la manía de adoctrinar». Poco después (20-12-1897), a propósito de Soledades de Martínez Ruiz, practicó la crítica epistolar con asomos polémicos entre protestas de amistad, lamentando que el futuro Azorín, «cediendo a idolatrías pasajeras», exagerara al declarar primer literato de su siglo a Leopoldo Alas. Asimismo le reprochaba que en su libro alternaran planteamientos profundos con vulgaridades «extraídas del dorso de un almanaque». Las reconvenciones culminaban con el rechazo de la idea defendida por Martínez Ruiz acerca de que todo modelo moral -místico, metafísico o utilitario- desde Epicuro a Guyau, se fundaba en el egoísmo más o menos consciente para evitar el dolor, la tristeza y las molestias de la vida. A Bueno, en cambio, estas ideas le parecían simplistas por la incompatibilidad entre moral individual y moral social, pronunciándose por la moral «mística» cuya expresión era la caridad, que al menos intentaba imponer «cierto renunciamiento al ejercicio de nuestras facultades perversas».

En su primera crónica literaria de 1898 («Decadencia», 10-1-1898), apresado por la contradicción entre elitismo y realismo populista, a partir de ciertas opiniones de Julio Burell sobre la «manía sociológica» que invadía los periódicos, cuestionaba la función de los jóvenes intelectuales - «señoritos» de clase ilustrada, nutridos «con la ciencia que rezuman las ubres universitarias»- empeñados en dispensar a las multitudes el maná que les había llegado 
de Darwin, Spencer, Stuart-Mill, Kropotkine «y otros dioses de la moderna sociología» cuyas palabras no llevaban traza de llegar a un pueblo que no sabía leer, «un pueblo amodorrado en la pasividad y en el quietismo, en el silencio interior absoluto». Descarriados iban los jóvenes sociólogos en su afán de despertar el instinto de protesta, sólo efectivo si derivaba de las necesidades materiales satisfechas y de una «cultura educatriz» que regulara la vida de los cerebros: «un pueblo no se solivianta si no es sobre la base de una alimentación suficiente; y aquí, en España, el hambre cierra todas las vías pasionales». Tras reconocerse influido por Ruskin y Nietzsche, Bueno se declaraba partidario de las «aristocracias intelectuales», distantes del "pueblo ignaro» pero capaces de sentir, a la vez que desdén, compasión y amor por él. Sin marcarse plazos ni vías prácticas, aquella necesidad educadora pasaba por alejarse de la escuela tabernaria y seguir la del Arte, puro o útil, incardinado éste con la obligada referencia a la literatura nacional: «Lo urgente aquí es hacer arte aprovechando elementos de la propia nacionalidad, extrayéndolos, según el ejemplo de Pereda y Galdós, de la entraña popular». Pero finalmente se inclinaba hacia la noción del arte por el arte: «Venga el arte en novelas, en cuadros, en estatuas, en partituras; vengan esas auras de remozamiento intelectual que Gabriel D'Annunzio espera de la literatura italiana, y entonces será llegado el momento de pasear a Marx, a Engels, y, quizás, quizás, al príncipe de Kropotkine, alma generosa como pocas, por las planas de nuestros periódicos...»

Bueno recurría de nuevo a la crítica epistolar («Sociólogos y artistas», 24-1-1898), esta vez dirigiéndose a Mariano de Cavia, para arremeter contra Unamuno - «escritor espartoso» cuya notoriedad apenas rebasaba «los límites de su muceta»-que había tildado a D'Annunzio de esteta decadente y plagiario. El crítico hacía la apología del escritor italiano contra los ataques que sufría en Francia y en España: «Para hacer arte, es menester que, a las primicias del temperamento se junten otras cualidades que rara vez suelen darse en los hombres que viven para una propaganda: desinterés, olvido de prejuicios y estilo; estilo ante todo». Siete días más tarde, a partir de las intervenciones del joven psicólogo José Verdes Montenegro y Montoro en el Ateneo, se interrogaba por «¿El espíritu nuevo?» y confirmaba con todo lujo de referencias su posición favorable al arte por el arte, sin excluir un precavido eclecticismo al admitir la posible convivencia de naturalismo, decadentismo, sensualismo, idealismo y misticismo. Shelley, Stendhal, Zola, Huysmans, Tolstoi, Dostoievski, Mæterlink, Ibsen, D’Annunzio -sin olvidar a los pintores prerrafaelitas Rosseti y Burne Jones- podían coexistir en función de la diversidad de los receptores: «Nada hay pernicioso dentro del arte; y una obra, por inmoral y extravagante que parezca, encuentra su público. No importa que la 
popularidad del artista no se extienda más allá de cinco personas. El número de los admiradores no hace al mérito de la obra ${ }^{8}$ ». Algo había cambiado en la redacción de la «Plana» desde que, un año atrás (19-7-97), en un pie de grabado anónimo titulado «El arte socialista», que representaba la figura de un pintor contemporáneo desnudo e indeciso ante el caballete, se ponía en duda la novedad de la moderna tendencia simbolista y se defendía la integración «esemplástica» o unificadora (Coleridge), del arte «bello-útil» ajustado en su forma a los preceptos estéticos, provechoso para la colectividad de acuerdo con las «miras sociológicas» defendidas por Guyau.

Los artículos de Bueno, la inhibición creciente de Navarro Ledesma y el gusto crepuscular incentivado por la derrota ultramarina, abonaron la entrada de nuevos colaboradores -Martínez Sierra ${ }^{9}$, Pío Baroja...- estableciendo una mínima cabeza de puente simbolista en el otoño de 1898 que tuvo como base una doble referencia a Mallarmé asociado a los nombres de Henri Cornuty, Valle Inclán y el jovencísimo Candamo ${ }^{10}$ (como articulista, destinatario $\mathrm{y}$ traductor, respectivamente). Es bien sabido que estos y otros colaboradores de «Plana del Lunes» se foguearon durante el año siguiente en La Vida Literaria, en Revista Nueva (Ruiz Contreras, 1946: 106-125) y en la Hoja literaria del País donde reaparecieron Baroja, Candamo y Martínez Sierra, pero no Navarro, Ovejero, ni Bueno, quizás lo suficientemente profesionalizados como para no insistir en acumular capital simbólico en una empresa donde la

8. Verdes Montenegro dictó dos conferencias (26 de enero y 9 de febrero) sobre «El nuevo espíritu en la literatura contemporánea», presumiendo el ocaso del neo misticismo, defendiendo el esteticismo d'annunziano y dedicando frases de simpatía a Zola por su actuación en el caso Dreyfus. De ellas se hizo extenso eco la prensa. Bueno se ocupó de la segunda disertación en El Globo entre semana («Impresiones literarias. El espíritu nuevo», 12 de febrero), mostrándose conforme con las tesis del conferenciante. A fines de octubre de 1898 el diario anunciaba la publicación en folletín de El preludio de Chopin, de León K.Tolstoi (hijo) traducido por Bueno y prologado por Verdes.

9. Su primera colaboración fue una dramatización lírica firmada escuetamente por Gregorio Martínez -nueve redondillas, bajo el título de "Confiteor», 8-8-1898- cuyo interés radica en observar el acentuado protagonismo psicológico de un sujeto lírico femenino.

10. La coincidencia de estos nombres en aquellos momentos la atestigua también Pío Baroja (1945: 78) al recordar que acudían con frecuencia a la redacción de Revista Nueva en 1899 donde colaboraron los tres. Ruiz Contreras (1946: 118-119, 310) recordaba que Candamo soñaba con poemas de Mallarmé y estaba tan deslumbrado por Cornuty que le servía de secretario. Fue él quien lo presentó en la revista donde publicó el artículo «A un indiferente» (25-3-1899). El «desmemoriado» ampurdanés se aventuraba al suponer que fue lo único que publicó en Madrid, ignorando su texto anterior en «Plana del Lunes». Andando el tiempo Candamo pergeñó una imagen grotesca de Cornuty -patojo, bisojo, mugriento- aunque sin restar un ápice a su decisivo papel como «teorizante» en la eclosión del modernismo en España («Prosas a la deriva. Juan Ramón Jiménez y la desintegración de la poesía», $A B C$ de Sevilla, 22-6-1958, p. 7). 
creciente presencia de jóvenes parece indicio de colaboración gratuita (Alonso, 2002: 44-49 y 104-111).

\section{«Golfos intelectuales»: González de Candamo}

Mientras la prensa diaria madrileña ignoraba la muerte del poeta francés (99-1898), la «Plana del Lunes» dedicó a su memoria un texto de Cornuty «A propósito de Mallarmé (19-9-1898) y la traducción libérrima sin firma, presumiblemente también de Candamo, de su prosa «La Pipa» (Divagations, 1897) publicada en el número siguiente bajo el marbete de «Los simbolistas». El artículo de Cornuty, sin pretensiones programáticas, sublimaba al poeta desaparecido como un hombre de conciencia, atormentado por la expresión, «hombre interior» cuya lectura intraducible exigía silencio y atención. Días después, en Madrid Cómico se le dedicó una página ilustrada bajo la firma de Arlequín, seudónimo de su director Jacinto Benavente ${ }^{11}$. En dicho artículo («Stéphane Mallarmé», 24-9-1898), con la «estéril y cruel ironía» que Cornuty atribuía al dramaturgo madrileño -según Ricardo Baroja (1969: 47)-, tras declararlo «ídolo de los decadentes, incoherentes, etc., iniciados por sobrenatural revelación en el esoterismo de su doctrina poética», terminaba absolviéndolo pero condenando burlescamente a sus imitadores simbolistas «esos ratés del Arte que no buscan la fuerza en sí mismos, sino en la bandera de que se amparan».

Entre las restantes colaboraciones de Candamo merecen mención la elegía en prosa lírica (1-8-1898) en memoria del frustrado poeta Emilio Covisa, muerto a los 17 años $^{12}$, y su respuesta a Verdes Montenegro por haber observado el descrédito de «la literatura de ideas» entre la «golfería literaria»-esteticista, decadentista- que la confundía con la «literatura de tesis». Ello motivó la arrogante autoafirmación del joven asturiano: «Tengo el gusto de contarme en el número de los que tal piensan: golfos intelectuales, o como quiera llamarlos el simpático Verdes».

Algo más que curiosa resulta en el mismo artículo ${ }^{13}$, compuesto a modo de dietario periodístico, su temprano juicio sobre la opera prima de María Lejárraga. El crítico simulaba husmear, con cierto talante cervantino, entre los

11. Seudónimo utilizado también en la revista La Vida Literaria, editada por Bernardo Rodríguez Serra, que Benavente dirigió en los primeros meses de 1899 (Rubio, 1982: 215).

12. Bien pudo ser Candamo quien consiguió que Benavente incluyera a título póstumo en Madrid Cómico (10-12-1898), un breve poema de su amigo Covisa: «Si yo fuera Dios», que apareció junto al soneto «Ella» de Manuel Machado.

13. «Impresiones de literatura. Páginas de un diario», 7-11-1898. 
EL GLOBO

\section{PLANA DEL LUNES}

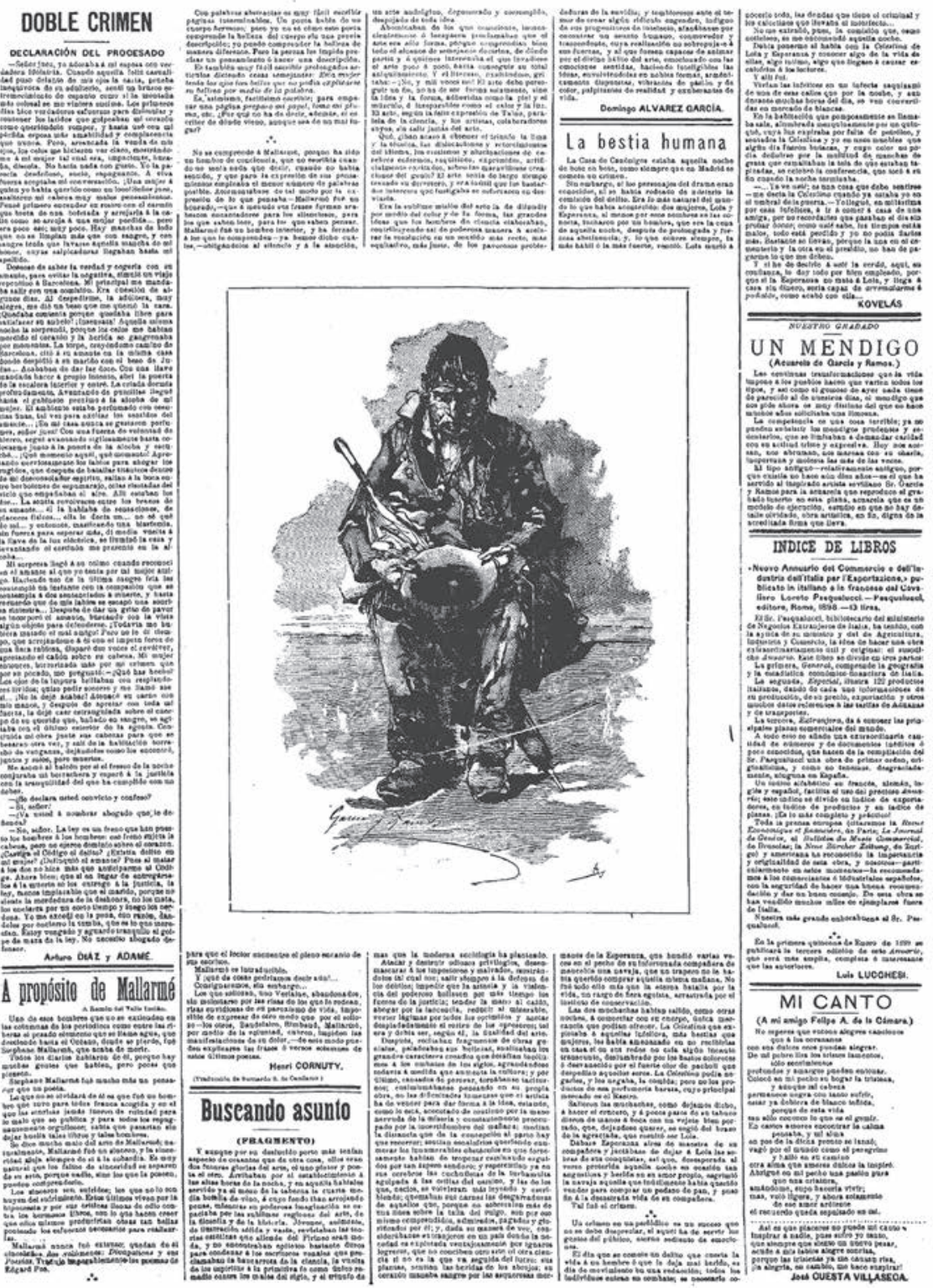

«Plana del Lunes», 19-9-1898 (BNE).

Anales, 26, 2014, pp. 43-80 
pliegos en rama hallados en una imprenta: «Hizo la casualidad que yo fijase la atención en alguno de los pliegos impresos de un libro nuevo. Me dijeron que estaba escrito por una mujer. Se llama la autora María Lejárraga, y el libro se titula Cuentos breves ${ }^{14}$. Los artículos que leí los encontré bien escritos; no carecen, sin embargo, de defectos. Los por mi preferidos son los titulados $\mathrm{La}$ inundación, Los abuelos y El gusanillo. En algunos he hallado gusto exquisito, sensaciones delicadas y frases ricas en matices y sonidos. En ellos se habla de genios, de niños y de corazones infantiles; son cuentos que recuerdan, por su niñez, las antiguas historias de castillos encantados y de hadas hermosas de cuerpo de espuma y de ojos inquietantes».

\section{Tendencias de la ficción narrativa}

Siendo el cuento el género literario dominante en este suplemento, su análisis pormenorizado nos permitiría apreciar la variedad temática, las modalizaciones narrativas -entre ellas la propuesta de «Cuentos-diálogos» por el albaceteño Fernando Franco Fernández (14-2, 7-3 y 25-7-1898) - y el deslinde entre fórmulas naturalistas, espiritualistas, regeneracionistas o simbolistas. En el espacio disponible nos limitaremos a reseñar que en 1897 se concentra la magra aportación literaria de Francos Rodríguez, limitada a una evocación narrativa de recuerdos estudiantiles («La blusa negra, 6-9-1897), lejano anticipo de sus futuras «Memorias de un gacetillero» y a tres cuentos propiamente dichos. El primero es una visión satírica del drama de honor, vivo en el teatro pero acomodaticio en la realidad, adornado con tópicos regeneracionistas y situado en un lugar de simbólica geografía -Quijanes- donde vegetaban «mangoneadores de la política local» $\mathrm{y}$ «señoritos herederos de casas vinculadoras, empobrecidas de todo, menos de alcurnia» («Comedia y realidad», 5-4-1897). Los otros dos son esbozos moralizantes sobre el anhelo femenino de triunfar en la vida mundana sin más medios que la hermosura, en procesos paralelos de desclasamiento predestinados a la destrucción («La última casa», 4-6-97; «La reina destronada», 29-11-97, éste con pinceladas clínicas de raíz naturalista). En el mismo periodo Jenaro González Carreño aborda el erotismo femenino en «Vicios del sistema» (19-7-1897) y José Rocamora, «Resurrección» (15-11-1897) funde en moldes clasicistas sensualismo erótico y una ilusoria redención espiritualista de carácter individual.

14. Se trata de Cuentos breves. Lecturas recreativas para niños (Madrid 1899). Véase Martínez Sierra (1953: 28-29). Por estas fechas la autora todavía no se había casado con Gregorio. 
No falta la alegoría política realista de añejo corte galdosiano con el bipartidismo reinante traspuesto al imaginario pueblo de Peñasa (David Miranda, «Guerra y paz» 28-6-1897). Hay episodios patrióticos minimalistas de exaltación heroica antes de la derrota (Rafael Maroto, «La Cruz Roja», 15-11-1897; Magdalena Santiago Fuentes, «Dos amores», 30-5-1898); Enrique Decoro, «El cabo Villoria, 27-6-1898). El dolor materno no resiste la ausencia del hijo en «La laureada» de Francisco Cortés (23-5-1898), ni en «La vuelta al hogar» de Calvín (7-2-1898) donde la moderna imagen de la «interminable caravana» de los primeros repatriados aparece flanqueada por la adjetivación naturalista más común: «desfigurados por las heridas, tísicos, anémicos, calenturientos, extenuados».

Tras la adversa conclusión de la guerra con los Estados Unidos, a partir de agosto de 1898, menudean simbolizaciones más o menos imprecisas, en forma de ansias frustradas de regeneración, temores inconcretos, personajes que deambulan desorientados por ciudades dormidas y solitarias, como ocurre en el antológico «Remordimiento» de Nicolás M. López (8-8-1898). La renuncia a la voluntad de vivir en respuesta a una sociedad injusta, ya patente en «Chaumet» de Rocamora (29-11-1897), se conjuga ahora con insatisfacciones existenciales y sentimentales en la crónica-cuento «Un día» (22-8-1898) del mismo autor y en «El suicida» (5-9-1898) de Calvín. Motivos de adversidades, autodestrucción, amores morbosos, naufragios, vicio y muerte hallamos en «La Poderosa» de Silverio de Ochoa; en «Sor Engracia» de Alfonso Fernández Ramos; en «Regenerado» de Andrés Aragón (los tres publicados el 29-8-1898); en «Un drama en el mar», intenso y medido relato todavía en clave naturalista de Gregorio Martínez Sierra (12-9-1898). «Retorno a la patria» de Manuel Navarro Alonso (5-9-1998) volvía al asunto de la repatriación tras el hecho irreversible de la derrota, sintetizando el proceso del gran fraude patriótico ya convertido en Historia, que se cerraba con la vuelta en el sollado del buque de «los humildes, aquéllos a quienes no se habían otorgado alabanzas ni ascensos, los infelices que un día salieran de sus hogares, fuertes y robustos, con plétora de vida, brazos arrancados al trabajo y a la industria y que ahora regresaban con rostros enflaquecidos que denotaban sufrimientos físicos inauditos y diezmados por las enfermedades del país», con el contrapunto de los acordes de «unos valses que en el piano del salón tocaba un pasajero de primera, sin que llegara a disipar la inmensa tristeza...». El motivo crepuscular se evidencia en el cuento de Magdalena Santiago «En el balneario (Crepúsculo)» (12-9-1898) que ponía como fondo a la desilusión amorosa de una cantante la «indeleble tristeza» acentuada al «declinar el crepúsculo» a través del lúgubre cristal de los recuerdos dolorosos. Asunto que alcanzaba 


\section{PLANA DEL LUNES:--CARNAVAL}
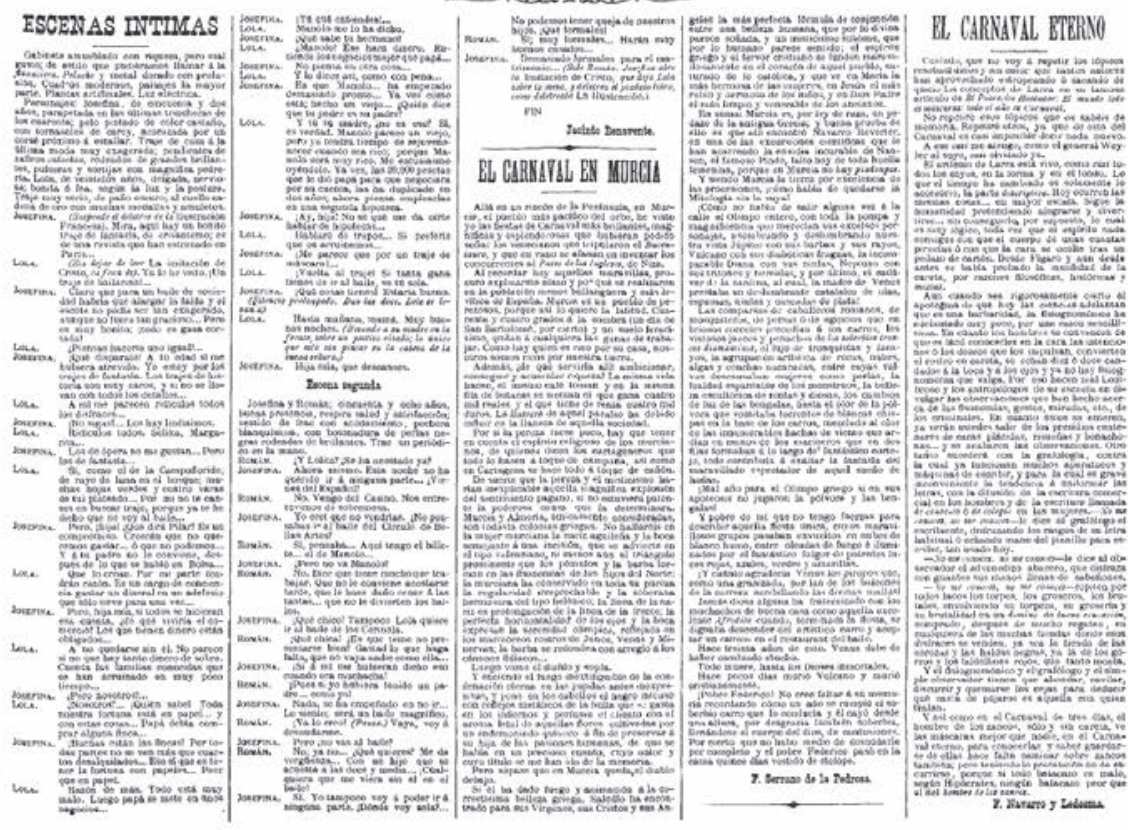

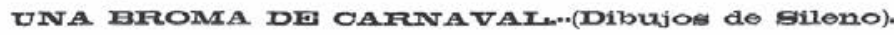
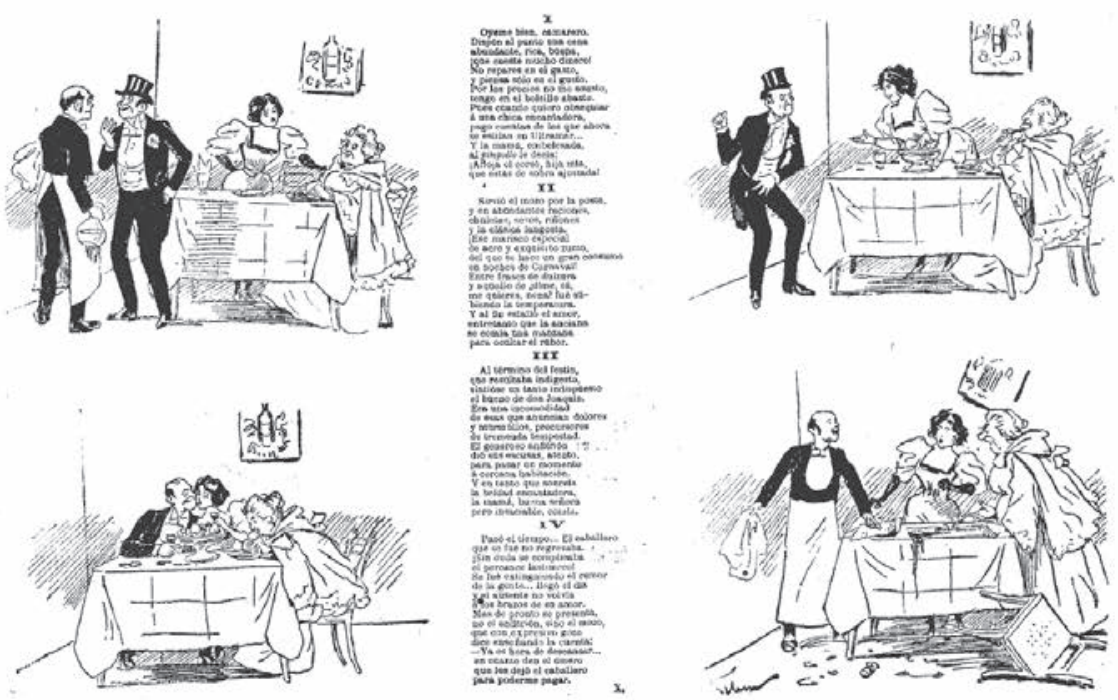

Primer número de «PlanadelLunes», ElGlobo 1-3-1897, único queincluyó caricaturas (BNE). 
mayores cotas literarias en uno de los cuentos que Pío Baroja ${ }^{15}$ había de incorporar a Vidas sombrías, «La playa en otoño» (7-11-1898), donde el discurso del amor perdido por María Luisa, la protagonista, cuyo punto de vista asumía con aliento neorromántico un narrador extradiegético extremadamente comprensivo, se expresaba con un lenguaje simbolista de "plazas desiertas», «piedras ennegrecidas», «gasas de nieblas», «brumas grises», «cielos cenicientos», «toques de campana» vibrando «en el aire empañado del angustioso crepúsculo», hasta culminar con la conciencia femenina del agotamiento vital, el presentimiento melancólico y desesperado de la decadencia física, tras el brillo momentáneo de la plenitud en que los espíritus de los amantes se habían fundido con las fuerzas cósmicas, «con el espíritu que late, en las olas, en las nieblas, en el mar inmenso».

$$
* * *
$$

Podría decirse que, en el amargo desconcierto de los últimos meses de 1898, esta «Plana del lunes» vino a ser estación de encuentro donde comenzaron a reunirse algunos de los viajeros interesados en tantear nuevos rumbos literarios y donde ensayó algunos de sus primeros pasos la avanzadilla de la inminente caravana modernista.

\section{Autores y títulos de «Plana del Lunes» (1897-1898)}

Año en negritas entre (). Títulos entre «» precedidos del día y mes de publicación. Entre [ ] notas

\section{Artículos firmados}

A. H.: (1898): 25-7: «El derecho de la fuerza. Cuento de actualidad» [cuento]

Aguilera y Arjona, Alberto: (1898): 21-3: «Carlos Peñaranda» [semblanza literaria y reseña crítica]

AlCAIDE DE ZAFRA, José: (1897): 19-4: «Hispalis!» [verso]

ALMENDROS CAMPS, José: (1898): 26-12: «La travesía» [avance libro nuevo, verso] ÁlvareZ GarCía, Domingo: (1898): 5-9: «El estreno de un artista» [cuento].- 199: «Buscando asunto (Fragmento)» [cuento].- 26-9: «La instrucción pública y la literatura» [opinión].- 7-11: «Vísperas solemnes» [cuento]

15. En su primera fase de El Globo, Baroja publicó otros dos textos: la estampa de «Los panaderos» (10-10-1898) donde anticipaba pinceladas «de la ancha llanura madrileña», que preludiaban La Busca; y su crónica «La forma es todo» (17-10-1898) -la forma de la moral social- reescrita con el título de «La condenada forma» para El Tablado de Arlequin (1903). 
ANDERSEN, Hans Christian: (1897): 11-10: «Cuentos escogidos. La última perla» [avance libro nuevo]

ARAGÓN, Andrés: (1898): 30-5: «Contrastes» [cuento].- 29-8: «Regenerado» [cuento].- 24-10: «La calavera fantástica» [cuento].- 28-11: «El retrato de Lilí» [cuento]

AraUS, Alberto: (1897): 5-7: «Un caso» [cuento]

ARTEAGA y PEREIRA, Fernando: (1897): 28-6: «Cantares» [avance libro nuevo, verso]

BALlesteros, Calixto [C. B.]: (1897): 3-5: «Amorosa (Fragmento)» [verso]; 2-8: «La Puerta Santa en la Catedral de Santiago» [divulgación histórico- religiosa].- 6-9: «Amorosa. Noche de estío» [verso].- 4-10 «Médicos ilustres. D. Alfredo Rodríguez Viforcos» [semblanza].- (1898): 31-1: «Una historieta vieja (con su correspondiente moraleja)» [verso narrativo]

BAROJA, Pío: (1898): 10-10: «Los panaderos» [cuento].- 17-10: «La forma es todo» [crónica].- 7-11: «La playa en otoño» [cuento]

BARredA, Luis: (1898): 14-3: «Cancionero montañés. Canción de Nochevieja. A Javier Bustamante» [verso]

BASELGA Y RAMÍREZ. Mariano: (1897): 3-5: «Cuentos de la era» [avance libro nuevo]

BENAVENTE, Jacinto: (1897): 1-3: «Escenas íntimas» [apunte dramático].- 12-4: «Escenas de La Divina tragedia» [traducción, teatro, v. Longfellow].-3-5: «La canción de la camisa de Tomás Hood (traducción del inglés)» [leyenda].17-5: «Oración fúnebre)» [crónica].- 7-6 «La última novela de Pérez Galdós (Notas de un lector)» [Misericordia, crítica literaria]

BLASCO, Eusebio: (1897): 17-5: «Corderos» [crónica].- 14-6: «Tedio. (Del libro «Corazonadas»)» [verso]

BLASCO IBÁÑEZ, Vicente: (1898): 28-11: «La barraca» [avance libro nuevo]

BOSQUE Y ROS, Ruperto: (1898): 8-8: «La verdad y la mentira. Fábula (pensamiento de Florián)» [verso].- 29-8, «El libro de la razón (Pensamiento de Aubert» [verso].- 12-9: «El loro. Fábula (Pensamiento de Lamotte)» [verso].- 2410: «La Caridad (Traducción de Victor Hugo)» [verso].- 31-10: «Ausencias. Soneto» [verso]

Bueno, Manuel [Lorena, M. B.]: (1897): 20-9: «Puesta de sol» [verso] y «El País vasco (Traducción directa)» [crónica].- [Lorena]: 15-11: «La mujer ideal» [debate feminista].- 13-12: «Crónicas literarias»[crítica literaria].- 20-12: «Crónica literaria. Para Martínez Ruiz en El Progreso» [crítica literaria, forma epistolar].- 27-12: [Lorena]: «Crónicas volanderas. Después de fiestas» [crónica]. (1898): 3-1: «Crónicas volanderas. «Novelerías»» [crítica literaria].10-1: «Crónicas literarias. Decadencia» [crítica literaria].- 24-1: «Sociólogos y artistas. Para Mariano de Cavia» [crónica literaria, forma epistolar].- 31-1: «¿El espíritu nuevo?» [crónica literaria].- 13-6: «Almas y paisajes» [avance 
de un libro en preparación].- [M. B.]: 20-6: «Índice de libros» [reseñas bibliográficas].-27-6: «Almas y paisajes» [avance, segunda entrega].- 18-7: «Rosas de té (En un álbum)» [verso]

C.R.: (1897): 22-11: «Índice de Libros» [reseñas]

CALVín Y RedONDO, Manuel: (1898): 10-1: «La confesión» [cuento].- 7-2: «La vuelta al hogar» [cuento de repatriados].- 28-2 «El beso del loco»[cuento].- 4-7: «La regata» [cuento].- 25-7: «El número 37» [cuento].- 5-9: «El suicida» [cuento].- 12-12: «La diva» [cuento].- 26-12: «Cuento de Navidad sin nacimiento» [cuento]

CAmbronero, Carlos: (1897): 12-7: «Los guantes del corregidor. Del libro inédito Historia de Madrid» [avance de libro nuevo].- 15-11: «La Regalía de aposento» [divulgación histórica].- 6-12: «Cosas de antaño. El Real de Manzanares. La sargentía mayor de Madrid» [divulgación histórica]. (1898): 31-1: «Cosas de antaño» [divulgación histórica]

CAMPO MORENO, J.: (1898): 25-7: «Indecisión» [cuento].- 17-10: «Luceritos» [verso]

CANDAmo, Bernardo G. de: (1897): 4-10: «Ensayos de crítica literaria. (D. Arturo Cotarelo y Mori)» [semblanza-reseña]. (1898): 1-8: «Elegía en prosa. Emilio Covisa (Ideas y sensaciones)» [prosa literaria].- 19:9: [Trad. de Cornuty: «A propósito de Mallarmé»].- 7-11: «Impresiones de literatura. Páginas de un diario» [reseñas críticas en forma de dietario]

CANO, Ricardo: (1897): 26-4: «Esclavitud» [crónica]; 19-7: «Versos».- «Versos» 6-9.- 13-9: «Versos» [Elegía III, lib. I de los Amores, de Ovidio].- 15-11: «Versos».- (1898): 24-1: «Versos»

CASANOVA, Sofía: (1897): 23-8: «Óyeme» [verso]

CASAS, Elisa: (1897): 31-5: «¡Era la misma!» «El falso espejo» [verso].- 20-9: «¡Bécquer! Mi vida es un erial...» [verso], «Cantares» [verso]

CASTOR Y POLUX (seud. de ¿ ?): (1898): 26-12: «Efemérides artísticas» [divulgación]

CASTRO Les, Vicente: (1898): 24-10: «Impresiones de las fiestas del Pilar» [crónica de actualidad]

Castro y Tiedra, Manuel [El Barón de Stoff]: (1897): 6-12: «Luchas del alma. Del libro "Novelerías", próximo a publicarse» [avance libro nuevo]. (1898): [El Barón de Stoff]: 8-8: «Amor extraño» [diálogo dramático].- [El Barón de Stoff]:: 26-9: «Los hijos de la Condesa» [cuento]

Ceballos, José G.: (1898): 12-9: «El periódico» [divulgación]

CHAMPBRUN: 24-10: (1898): «Tijera en mano» [recortes de prensa]

COPPÉE, François: (1897): 27-12: «Nochebuena imperial» [cuento]

Cordero Velasco, F: (1897): 10-5: «A Dolores» [verso]

CoRnuty, Henri: (1898): 19-9: «A propósito de Mallarmé. A Ramón del Valle Inclán» [semblanza crítica] 
CORTÉS, Francisco: (1897): 6-9: «Cuento. El Cristo de los Milagros»[cuento].29-11: «Un devaneo» [cuento]. (1898): 23-5: «La laureada» [cuento de guerra].- 22-8: «Visitas artísticas. En el estudio de Juan Aldaz» [crónica de arte].- 31-10: «Represalias» [cuento]

Cuesta Villaseca, José: (1898): 19-9: «Mi canto. (A mi amigo Felipe A. de la Cámara)» [verso]

D. M.: (1897): 22-3: «Sociedad de Conciertos» [gacetilla musical]

DECORO, Enrique: (1898): 27-6: «El cabo Villoria. (Recuerdos de Filipinas)» [cuento de guerra]

DEL, Rafael: (1898): 6-6: «Los impertinentes de Juanita» [cuento]

DiCENTA, Joaquín: (1898): 4-7: «Los jóvenes. (Del libro Crónicas)» [avance libro nuevo]

DíAZ Y ADAME, Arturo: (1898): 19-9: «Doble crimen. Declaración del procesado» [cuento]

DíEZ ViCARIO. V. de: (1898): 24-1: «Desde el destacamento. Impresiones de Nochebuena» [crónica de guerra]

E.S.: (1897): 22-11: «Índice de Libros. Una obra de utilidad» [reseña bibliográfica] EL BEDEL SOTELO (seud. de i?): (1898): 3-10: «Un buen estudiante» [semblanza de José Goyanes]

ELEDECÉ (seud de i?): (1898): 14-3: «La extinción de una raza» [divulgación]

ESCALANTE GÓMEZ, Manuel: (1898): 28-2: «A un arroyo» [verso]

FELIU Y CODINA, J.: (1897): 10-5: «Mi huella (Inédito)» [verso]

FERNÁNDEZ FLÓREZ, Isidoro: (1898): 14-11: «Fragmentos del Discurso del Sr. Fernández Flórez. La literatura de la prensa» [información actualidad]

FERNÁNDEZ RAMOS, Alfonso: (1898): 22-8: «El cornetilla» [cuento de guerra].29-8: «Sor Engracia» [cuento]

FERNÁNDEZ Y SÁNCHEZ, Ildefonso: (1898): 4-4: «Recuerdos del Madrid Viejo. Bernardino de Obregón» [crónica histórica].- 2-5: «Los héroes del Dos de Mayo» [semblanzas patrióticas].- 18-7: «La religión de los recuerdos»[crónica de actualidad]

FÍGARO: 1-11: (1897): «El día de difuntos de 1836. Fígaro en el cementerio» [conmemoración]

FRANCÉS, José María: (1898): 20-6: «Tipos filipinos» [avance libro nuevo]

FRANCO FERNÁNDEZ, Fernando: (1897): 23-8: «Escena íntima» [diálogo dramático].- 11-10: «Otoñal» [verso].- 8-11: «La estatura» [verso]. (1898): 7-2: «Soneto» [verso].- 14-2: «Cuentos- diálogos. Ingrata» [cuento].- 21-2: «Piñata»[cuento].- 28-2 «Indiferencia» [verso].- 7-3: «Cuentos-diálogos. La veda. A Enrique Sepúlveda» [cuento].- 4-7: «Sonetos» [verso].- 18-7: «Mi ambición (soneto)»[verso].- 25-7: «Cuentos-diálogos. El único plan. A mi respetable amigo D. José Francos Rodríguez» [cuento].- 12-9: «De 
viaje» [cuento].- 21-11: «Enferma (En la caída de la hoja)» [verso].- 28-11: «Amorosa» [verso]

FrANCOS RodríGUEZ, José: (1897): 5-4: «Comedia y realidad» [cuento].- 28-6: «La última casa» [cuento].- 6-9: «La blusa negra» [memorias].- 29-11: «La reina destronada» [cuento]. (1898): 14-2: «Médicos españoles. El Doctor D. Eugenio Gutiérrez» [semblanza].- 17-10: «El Doctor Castro» [semblanza]

GALVARRIATO, J. A.: (1897): 4-10: «El anónimo» [debate periodístico]

GANIVET, Ángel: (1897): 23-8: «Del "Idearium español”» [avance libro nuevo]. (1898): 5-12: «Los borrachos (De las Cartas Finlandesas)» [ensayo]; «El carácter español (De Granada la Bella)»; «Del Idearium español» [ensayo]

GAST, Camille du: (1897): 22-3: «Los dos rivales» [cuento]

GIL, Ricardo: (1898): 4-4: «Non est hic (Del hermoso libro La caja de música)» [avance libro nuevo, verso]

GIL, Rodolfo: (1897): 13-9, «Oro de ley» [avance libro nuevo, verso]

GIMENO DE FlaQUER, Concepción: (1897): 26-4-: «Grecia»[divulgación].- 3-5: «Madrid elegante» [crónica de salones].- 23-8: «Cuentos breves. Por no amar» [cuento].- 13-9: «La edad de la mujer» [crónica femenina].- 22-11: «Semblanzas femeninas. S.A.R. la Infanta doña Isabel» [etopeya]. (1898): 10-1: «La mujer asturiana» [costumbrismo].- 7-3: «Semblanzas femeninas. Americanas célebres. Excelentísima Señora Doña Carmen Romero Rubio de Díaz» [etopeya].- 22-8: «El médico» [divulgación]

GÓMEZ-QUINTERO Y CALÉ, L.: (1897): 18-10: «La colcha blanca» [cuento-leyenda] GONZÁlEZ CARREÑO, Jenaro: (1897): 19-7: «Vicios del sistema» [cuento].- 6-9: «El secreto del amor» [cuento].- 13-9: «Manos blancas» [cuento].- 4-10: «Idiotismo y coquetería» [cuento].- 25-10: «Predestinado» [cuento]

GonZÁlez LlanA, M. y Francos RodríGUEZ, José: (1897): 8-3: «Los plebeyos...» [fragmento dramático]

GRANDA, Jesusa de: (1897): 17-5: «Primaverales. Luz» [prosa literaria].- 14-6 «Cadenas» [prosa literaria].- 2-8: «Pensamientos» [aforismos].- 25-10: «El cansancio» [divulgación higiénica, trad. del francés]. (1898): 25-7: «Fuerza suprema» [cuento]

GRANDE BAUDESSON, Luis: (1898): 25-4: «Con motivo de la corrida nacional (Cuento)» [cuento alegórico]

GRILO, Antonio F.[ernández]: (1897): 5-7: «El primer beso» [verso]

IÑARRA, Javier: (1898): 18-7: «La última rosa» [cuento]

HeRnANDO DE EsPINOSA, Dr. Benito: (1898): 3-10: «Cisneros» [semblanza]

HERRERA, José J.: (1897): 5-4: «Dos poetas de amor» [avance libro nuevo, verso]

J. T. F., Doctor: (1898): 7-3: «La higiene pública» [divulgación médica]

KovelÁs (seud. de i?) [corresponsal en Madrid de Revista Gallega en 1895].

(1898): 19-9: «La bestia humana» [cuento-crónica]

L. P.: 25-4: (1898): «Un monumento de Querol» [crónica artística]

Anales, 26, 2014, pp. 43-80 
LAMBROS, S.P. 15-3: (1897): «Los juegos olímpicos» [historia antigua]

LE ROY, Edmond: (1897): 27-9: «El parecido en el teatro» [actualidad teatral francesa]

LONGFELLOW, Henry Wadsworth: (1897): 12-4: «Escenas de La Divina tragedia. (Traducción del inglés)...» [teatro]

LÓPEZ, Nicolás María: (1898): 25-7: «Tarde granadina» [cuento].- 1-8: «Última postura»[cuento].- 8-8: «Remordimiento» [cuento alegórico].- 22-8: «El veleta» [crónica paisajística].- 17-10: «Episodio del drama universal» [cuento].- 28-11: «Carta jaculatoria» [cuento, forma epistolar]

LÓPEZ SILVA, J.: (1897): 26-4: «Nuestros mendigos» [verso]

LUCHESSI, Luis: (1898): 19-9: «Índice de libros» [reseña bibliográfica]

MACIEL, Santiago: (1898): 27-6: «Iberia» [verso]

MALlarmÉ, Stéphane: (1898): 26-9: «La pipa (Página de Mallarmé)» [traducción de Divagations]

MALO, Doctor: (1897): 13-12: «Medicina popular. Lucha contra la tisis. VII» [divulgación]

MALUQUER Y SALVADOR, Manuel: (1898): 17-1: «El último invento» [crónica tecnológica]

MAntegazzA, Paolo: (1897): 13-12: «Literatura italiana. Sinfonía extraña» [aforismos]

MARoto, Rafael: (1897): 15-11: «La Cruz Roja (Episodio)» [cuento de guerra].22-11: «Rojo y azul» [verso]. (1898): 21-2: «Confetti» [verso]

MARTínez FALERO, R.: (1898): 8-8: «Nubes fugaces» [cuento]

Martínez Orozco, F: (1897): 31-5: «Buen tiempo» [cuento]

MARTÍNEZ SIERRA, Gregorio: (1898): 8-8: «Confiteor» [verso].- 12-9: «Un drama en el mar (cuento)».

MínIMO (¿seud. de...?: (1897): 22-3 «El Puente de Segovia» [divulgación].- 26-4: «El viático en la aldea» [verso].- 24-5: «Índice de libros» [reseñas].- 31-5: «Estatua de Alfonso XII» [crónica informativa].- 2-8: «Crónica de la semana» [actualidad].- 20-9: «El castillo da Penha» [divulgación histórica].- 279: «El individualismo literario» [crítica literaria].- 22-11: «El músico callejero» [pie de grabado].- 6-12: «Al amor de la lumbre» [verso].- 13-12:«Un mercado en Murcia» [pie de grabado].- 20-12: «El "record" del feminismo» [verso satírico].- 27-12: «La gruta de Belén» [pie de grabado]

Miranda, David: (1897): 28-6: «Guerra y paz» [cuento]

MOLINA DE LA TORRE, E.: (1897): 15-11: «Severo» [verso]

Mompeón Motos, Antonio: (1898): 21-11: «La mejor obra (Cuento)» [cuento]

MORERA Y GALICIA, M.: (1897): 19-7: «Marinas leiquitianas» [verso]

NANFREDO (seud. de...?): (1897): 19-4: «Sevillanas» [crónica].-26-4: «Sevillanas. El real de la Feria» [crónica] 
NAVARRETE, José: (1898): 31-10: «Niza y Rota (Un libro de Navarrete)» [avance libro nuevo]

NAVARRO AlONSO, Manuel: (1898): 5-9: «Retorno a la patria» [cuento de guerra] NAVARRO Y LEDESMA, F: [F.N.L., N.] (1897): 1-3: «El carnaval eterno» [crónica].15-3: «Paráfrasis de un soneto "helénico" de Heredia. Epigrama votivo» [verso].- 15-3: «Un "Gedeón” griego».- [divulgación histórica].- 29-3: «Genio y figura» [crítica literaria] - 5-4: Un libro raro» La conquista del reino de Maya por el último conquistador español Pío Cid] [crítica literaria].- 10-5: «Exposición de Bellas Artes. Visita anticipada» [crítica arte].- 17-5: «Misericordia. (Novela de D. Benito Pérez Galdós)»[crítica literaria].- 31-5; 7, 14, 28-6; 5 y 19-7: «Exposición de Bellas Artes. (Notas de un aficionado)» [crítica arte].- 2-8: [N.]: «Una guitarra nueva» [reseña libro de versos con antología].- 27-9: «Oraciones por Santiago Rusiñol...»[prosa, trad. del catalán].- 1-11: «La muerte de la muerte» [crónica filosófica].- 29-11: [N.]: «La Floralia (Cuadro de Antonio Reina Menescau)» [pie de grabado].- 6-12: «El abuelo. (Notas sueltas)» [crítica literaria].- 27-12: «Nochebuena en el Parnaso. Diálogo pseudo-filosófico» [diálogo dramático]. (1898): 7-2: «Poetas del amor. Versiones de Kalidasa y de Heine por José J. Herrero» [crítica literaria] .- 21-2: «Carnal y carnaval» [divulgación histórico-literaria].- [F.N.L.]: 30-5: «Índice de Libros. Novelas cortas» [crítica literaria].- 6-6: «Zumalacárregui» [crítica literaria].- [F.N.L.]: 14-11: «Un Lunático, Fernanflor, Fernández Flórez» [semblanza].- 5-12: «Ángel Ganivet y García» [necrológica]

NeBLIS, P. de: (1898): 14-2: «La klecksografía» [divulgación técnico-artística].28-2: «Recuerdos de antaño. Un amigo menos» [necrológica].- 14-3: «Su Majestad el reclamo» [crónica]

OchOA, Rafael: (1897): 8-11: «Noche de Cádiz (soneto). A mi bellísima amiga Petra Ruiz» [verso].- 22-11: «El Cristo de mi Iglesia. Soneto. A mi ilustre y muy querido amigo el artista de la palabra D. Antonio Maura» [verso].- 1312: «El alcázar de Segovia. A mi ilustre y querido amigo el general Martínez Campos. Soneto» [verso]

OchоA, Silverio de: (1897): 12-4: «Loca de celos» [cuento].- 10-5: «Duburuya» [cuento].- 14-6: «Cascabeles» [cuento].- 23-8: «Los dos caminos» [cuento].- 11-10: «Don Ténico» [cuento].- 18-10: «El respeto a la ley» [cuento].- 25-10: «Venganza campesina» [cuento].- 20-12: «Nobleza» [cuento]. (1898): 3-1: «Tarjeta de año nuevo» [cuento].- 7-2: «Las cometas» [cuento].- 14-2: «Historia de un clavel» [cuento].- 14-3: «Los talismanes del Bracman Kiak» [cuento hindú].- 23-5: «Amores de un ciego» [cuento].-6-6: «Sor Nati» [cuento].- 13-6: «El rincón de la huerta» [cuento].- 27-6: «La subida del puerto» [cuento].- 18-7: «La leyenda de Peña Citores» [cuento-leyenda].- 8-8: «El mejor libro» [cuento oriental].- 29-8: «La poderosa» 
[cuento].- 17-10: «La deidad "imposible" » [cuento].-26-12: «Escenas castellanas. En el encinar» [cuento]

Olmedilla y PUiG, Dr. Joaquín: (1897): 11-10 «Eduardo Jenner» [semblanza]

OSSORIO Y BERNARD, Manuel: (1897): 8-3: «Teodora Lamadrid» [semblanza en verso].-

Ovejero, Andrés: (1897): 15-3: «Grecia» [crónica elegiaca]: 29-3 «Don Juan Valera» [semblanza].-5-4: «Recuerdos. Monólogo» [monólogo dramático].12-4: «Cristo en el cementerio» [crónica].- 19-4: «La catedral de Sevilla» [crónica].- 3-5: «Don José Feliu y Codina» [semblanza].- 10-5: «Héroes de Fuerte Victoria» [crónica de la guerra].- 24-5: «Las cigüeñas de Estrasburgo» [crónica].- 30-8: «Francia y Rusia» [actualidad].- 27-9: «Los tres amigos. (A Rosarito C.)» [verso]

OvejERo y MAURY, Mariano: (1898): 19-12: «La cabeza por adorno» [cuento]

P. S.: (1897): 29-11: «Paseo por Europa» [revista de prensa]

PAlacios GARCía, Carlos: (1897): 11-10: «A medias» [verso]

PAlaU, Melchor de: (1897): 12-4: «Del Poema inédito Una historia de amor» [verso]

PAZ, Abdón de: (1898): 21-11: «El Concejo» [avance libro nuevo]

Pereyra de ARMas, Miguel: (1897): 18-10: «Tipos de mi tierra. El boticario viejo. Abril 1896» [avance libro nuevo]

PiCATOSTE, Valentín: (1897): 17-5: «Cuenca» [avance libro nuevo].- (1898): 213: «Granada» [avance libro nuevo]

Politis, N. G., 15-3: (1897): «Atletas» [Historia antigua]

Potous, Juan José: (1898): 20-6: «Puerto Rico. La capital y la isla» [divulgación geopolítica]

POYATOS, Felipe, cura párroco de San Andrés: (1897): 12-7: «El discurso de un párroco. La educación en el distrito de la Latina de Madrid» [divulgación] REDONDO Y MENDUIÑA, Juan: (1898): 6-6: «El árbol» [verso; avance libro nuevo] ROCAMORA, José [Tersites]: (1897): 15-11: «Resurrección» [cuento].- 29-11: «Chaumet» [cuento]. (1898): 3-1: «Solidaridad (Cartas perdidas» [crónicacuento, forma epistolar].- Tersites: 17-1: «Instantánea» [divulgación científica].- Tersites: 24-1: «Instantánea. Ansiedades infantiles» [pie de grabado].Tersites: 31-1: «Instantánea. Los dos amigos» [pie de grabado].- 7-2: «Ángeles (Soliloquios de un marido)» [cuento].- 4-4: «La crisis de Juan Martel» [cuento histórico].- Tersites: 22-8: «Un día» [crónica]

RODAO, José: (1897): 13-12: «Fabulillas. La presunción de los débiles» [verso] Rodríguez Pinilla, Cándido: (1898): 7-11: «Cantos de la noche» [avance libro nuevo, verso]

ROMAÑA, Ulpiano: (1898): 25-4: «¡Viva España!» [verso]

RUEDA, Salvador: (1897): 15-3: «El golpe (soneto)» [verso].- 22-3 «Dos Sonetos» [verso] 
RUSIÑOL, Santiago: (1897): 27-9: «Oraciones por Santiago Rusiñol» «Traducido del catalán por F.N.L.» [avance libro nuevo]

SALILLAS, Rafael: (1897): 24-5: «¿Qué es el periódico?» [reseña crítica]

SANCHís, Vicente [Miss-Teriosa]: (1897): 1-11: «Las dos madres» [crónica sobre la guerra].- [Miss-Teriosa]: 22-11: «La hembra de Caín» [crónica-cuento].[Miss-Teriosa]: 6-12: «Índice de libros. Le repórter, novela contemporánea por Paul Brulat». [reseña crítica]. (1898): [Miss-Teriosa]: 24-1: «Cleopatra» [crítica teatral].- [Miss-Teriosa]: 21-2: «Un ballo in maschera» [cuento].[Miss-Teriosa]: 28-2: «Balas y caramelos» [cuento].- 7-3: «Isolda. El código del honor» [avance libro nuevo].- [Miss-Teriosa]: 21-3: «Eleonora» [cuento].- [Miss-Teriosa]: 4-4: «Uno siquiera (Recuerdos de los Estados Unidos)» [crónica de actualidad militar].- 18-4: «Nuestro adversario. (Recuerdos de los Estados Unidos)» [carta abierta a Francos Rodríguez, crónica de actualidad].- [Miss-Teriosa]: 25-4: «Nuestro adversario. (Recuerdos de los Estados Unidos)» [invectiva, carta abierta al embajador estadounidense, Steward Woodford].- 15-8: «En el extremo Oriente» [actualidad política]

SANDOVAL, Manuel de: (1898): 14-3: «Fugaces» [reseña crítica]

SAntiago FuEnTES, Magdalena: (1898): 30-5: «Dos amores» [cuento].- 12-9: «En el balneario (Crepúsculo)» [cuento]

SANZ CASANOVA, Abraham: (1897): 22-11: «Romeo y Julieta» [cuento]

SANZ OBIETA, Carlos: (1898): 26-12: «Diálogos íntimos» [cuento en forma epistolar] SEA, A.: (1897): 8-3: «Notas parisienses. El Carnaval en París...» [correspondencia francesa].- 29-3: «Panamá, Artón y Compañía» [correspondencia francesa].- 7-6: «Canción de estío» [prosa poética].- 8-11: «París, Noviembre 1897» [cuento epistolar]. (1898): 1-8: «París, Julio 1898» [cuento epistolar] SERRANO DE LA PEDROSA, Francisco [F.S.P.] (1897): 1-3: «El carnaval en Murcia» [divulgación etnografía y folclore].- 8-3: «¡Cuándo se acabará» [crónica].29-3: «El porvenir de los chicos» [crónica].- 3-5: «El moscón» [cuento dialogado].- 24-5: «La mala letra» [crónica humorística].- 14-6: «Las cuatro esquinas» [costumbres literarias].- 2-8: «Los tiesos» [tipos y costumbres].20-9: «La talenta» [cuento].- 27-9: « Pchs! No le conocía» [cuento]. (1898): F.S.P., 28-2: «La Caja de música» [reseña crítica]

SilBÉN, Pío: (1897): 4-10: «¡Pedaleando!» [costumbres de actualidad].- 8-11: «La Prensa y el Correo» [divulgación].- 20-6 «Quisicosas» [cuento]. (1898): 1010: «Las apariencias engañan. Historia que parece cuento» [cuento]

SOLER, Antonio: (1897): 25-10: «Minucia» [verso].- 27-12: «La visita del diablo. (Cuento)» [verso]. (1898): 1-8: «Minucias» [verso]

T.: (1898): 25-7, «Nuestro grabado. Luchar por la vida» [pie explicativo]

TERÁN, Luis de: (1897): 12-7: «Importancia científica de la expedición de Nansen» [divulgación].-8-11: «Plaza partida" por Don Luis Siboni» [reseña crítica].20-12: «Alfonso Daudet» [necrológica] 
TERCERO, Manuel: (1898): 5-9: «Un ideal» [cuento].- 10-10: «Desprecio» [cuento] TORROBA, José: (1898): 21-11: «Notas de Inglaterra. Ruskin. I» [estudio crítico].12-12: «Notas de Inglaterra. Ruskin. II» [estudio crítico].- 19-12: «Notas de Inglaterra. El ejército de salvación» [crónica]

TORROMÉ, Rafael: (1897): 8-3: «La casa de la Emperatriz» [cuento]

TURGUENEW, Ivan: (1897): 4-10: «Maruja (Traducción directa)» [cuento]

VAlerA, Juan: (1898): 14-11: «Contestación de D. Juan Valera» [a Fernández Flórez, discurso]

VALLE, Albert del: (1898): 7-3: «Hojas sueltas. Voluntad» [cuento]

VEGA, Lope de: (1898): 3-10: «Soneto» [verso]

Velasco García, Víctor: (1898): 1-8: «El beso» [cuento].- 12-12: «El primer artículo» [cuento]

Vila VelasCO, J.: (1897): 22-3: «La barrera del once» [cuento]. (1898): 21-2: «El capuchón verde» [cuento].- 26-9: «Infidelidad» [cuento]

X.: (1897): 13-12 «Inauguración de un Hospital modelo» [divulgación]. (1898): 21-2: «Batalla de flores» [versos].- 21-3: « ¡Misterio! Escena íntima» [diálogo dramático]

\section{Artículos sin firma}

1897

«A orillas del río» 19-7 [pie de grabado]

«Bermeo, 12-7 [divulgación]

«Bibliografía europea. Noticias al vuelo», 13-9 [actualidad bibliográfica]

«Buenos Aires», 14-6 [pie de grabado, divulgación]

«Cervantes y sus modelos», 18-10 [pie de grabado]

«Costumbres de la China», 28-6 [divulgación]

«Don Joaquín Sorolla», 31-5 [semblanza]

«El arte socialista», 19-7 [pie de grabado]

«El maestro Pini», 12-4 [semblanza]

«El Prólogo de "Los Pirineos"», 22-3 [reseña musical]

«El secreto sorprendido», 23-8 [pie de grabado]

«Enriques famosos», 19-7 [divulgación]

«Espectáculos» 6-9 [cartelera]

«Exposición de Bellas Artes. Fecha de inauguración, 25 de mayo», 22-3 [gacetilla]

[Francisco] «García Ayuso»,17-5 [necrológica]

«Índice de libros», 29-3 [reseñas]

«La ciudad de Rotterdam», 4-10 [divulgación]

«La pena capital en España» por Don Ángel Pulido, 5-7 [reseña crítica]

«Nuestro grabado», 25-10 [pie de grabado]

«Nuestro grabado. Calle Mayor de Fuenterrabía», 13-9 [pie de grabado]

Anales, 26, 2014, pp. 43-80 
«Nuestro grabado. Diana y Calisto. Cuadro de Ticiano Vecellio», 11-10 [pie de grabado]

«Para comer bien....», 2-8; 6-9 [publicidad]

«Puente en San Francisco de California», 8-11 [pie de grabado]

«iQué quieres? Cuadro de P. Nife» 7-6 [pie de grabado]

«Un mercado en Cataluña», 15-11 [pie de grabado]

«Yamagata», 12-7 [actualidad]

1898

«Alegría. (Cuadro de R. Arroyo Fernández)», 13-6 [pie de grabado]

«Año Nuevo», 3-1 [crónica]

«Curiosidades. Experimento curioso», 25-7 [divulgación]

«Doctor D. Benito Hernando de Espinosa», 3-10 [semblanza]

«El Discurso inaugural», 3-10 [información, actualidad]

«El Ferrocarril circular de la Exposición de 1900», 4-7 [divulgación]

«El Madrid de los recuerdos», 14-2 [reseña bibliográfica]

«Globos cautivos en el mar», 7-2 [pie de grabado]

«Índice de libros», 18-7 [sección bibliográfica]

«Índice de libros. El libro de Desmoulins», 31-10 [reseña bibliográfica]

«La cremación de cadáveres», 23-5 [actualidad parisién]

«La guerra en Europa», 4-7 [divulgación militar]

«La Universidad de Alcalá (después Central)», 3-10 [divulgación]

«Nuestro grabado», 6-6 [pie de grabado]

«Nuestro grabado», 18-7 [pie de grabado]

«Nuestro grabado», 1-8 [pie de grabado]

«Nuestro grabado. Al borde del precipicio (Cuadro de A. Seiquer)», 10-10 [pie de grabado]

«Nuestro grabado. Anfiteatro de la Sorbona», 26-9 [pie de grabado]

«Nuestro grabado. Bombardeo de Alejandría», 8-8 [pie de grabado]

«Nuestro grabado. Caballería española», 30-5 [pie de grabado]

«Nuestro grabado. Caza (Cuadro de Julia Alcayde)», 7-11 [pie de grabado]

«Nuestro grabado. Cercanías de Roma. Cuadro de Serra», 29-8 [pie de grabado]

«Nuestro grabado. D. Vicente Sanchís», 7-3 [pie de grabado]

«Nuestro grabado. El boulevard des Capucines», 14-3 [pie de grabado]

«Nuestro grabado. El tranvía eléctrico», 27-6 [pie de grabado]

«Nuestro grabado. La conjura», 22-8 [pie de grabado]

«Nuestro grabado. La escabicheira (Cuadro de Pradilla)», 21-11 [pie de grabado]

«Nuestro grabado. La lechera», 28-11 [pie de grabado]

«Nuestro grabado. Nuevos buques de vela», 23-5 [pie de grabado] 
«Nuestro grabado. Ruega por nosotros pecadores... (Cuadro de R. Pulido», 5-9 [pie de grabado]

«Nuestro grabado. Un mendigo (Acuarela de García y Ramos)», 19-9 [pie de grabado]

«Nuestro grabado. Un paje (Acuarela de Manresa», 26-12 [pie de grabado]

«Nuestro grabado. Una lección de canto (Cuadro de Schoesser)», 24-10 [pie de grabado]

«Nuestro grabado. Una serrana», 19-12 [pie de grabado]

«Nuestros grabados. Contraste.- (Cuadro de E. Vivó Tarín.- Dar de comer al ham-

briento (Cuadro de F. Godoy)», 12-9 [pie de grabado]

«Pánico en un gallinero», 28-2 [pie de grabado]

«Prosa y versos», 12-12 [reseña bibliográfica]

«Reparto de ganancias», 10-1 [pie de grabado]

«Un duelo por Emilio Zola», 14-2 [actualidad intelectual]

«Un libro útil», 4-7 [reseña bibliográfica]

\section{Bibliografía citada}

Alberola, Ginés, Emilio Castelar (Memorias de un secretario), Madrid, Imprenta «Prensa Española», 1950.

AlOnso, Cecilio, «Textos efímeros del 98», en Juan Carlos Ara y José Carlos Mainer, eds., Los textos del 98, Valladolid, Universidad de Valladolid, Centro para la Edición de los Clásicos Españoles, 2002, pp. 7-111.

- Índices de Los Lunes de El Imparcial (1874-1933), en colaboración con Encarna Marín Pérez, Madrid, Biblioteca Nacional, 2006.

BAROJA, Pío [1944], Desde la última vuelta del camino. II. Familia, infancia y juventud, 2. ${ }^{a}$ ed., Madrid, Biblioteca Nueva, 1951.

-, Desde la última vuelta del camino. III. Final del siglo XIX y principios del XX, Madrid, Biblioteca Nueva, 1945.

BAROJA, Ricardo [1935], Gente del 98, en Obras Selectas, Madrid, Biblioteca Nueva, 1969.

BARRIOBERO Y HERRÁN, Eduardo, De Cánovas a Romanones. La bancarrota nacional, Madrid, Imp. A. Marzo, 1916.

CASTILlo, Santiago J., «La prensa diaria de Madrid: notas para el análisis de las estadísticas del timbre», en M. Tuñón de Lara et al., Prensa y sociedad en España (1920-1936), Madrid, Edicusa, 1975, pp. 149-198.

DesvoIS, Jean Michel, La prensa en España (1900-1931), Madrid, Siglo XXI, 1977.

Francos Rodríguez, José, El año de la derrota. 1898, Madrid, C.I.A.P., 1930.

Martínez Sierra, María, Gregorio y yo. Medio siglo de colaboración, México, Biografías Gandesa, 1953. 
OSSORIO y BERnARD, Manuel, [1903], Ensayo de un catálogo de Periodistas Españoles del siglo XIX, Madrid, Imp. y Lit. de Palacios. Edición facsímil, Madrid, Hemeroteca Municipal, 2004.

París, Luis, Gente nueva. Crítica inductiva, Madrid, Imp. Popular de El Motín, 1889.

Rubio JimÉnEZ, Jesús, Ideología y teatro en España: 1890-1900, Zaragoza, Universidad de Zaragoza, Departamento de Literatura, 1982.

Ruiz Contreras, Luis, Memorias de un desmemoriado, Madrid, Aguilar, 1946.

Zulueta, Carmen de, Navarro Ledesma. El hombre y su tiempo, Madrid, Alfaguara, 1969.

Fecha de recepción: 11/05/2014

Fecha de aceptación: 31/07/2014

Anales, 26, 2014, pp. 43-80 


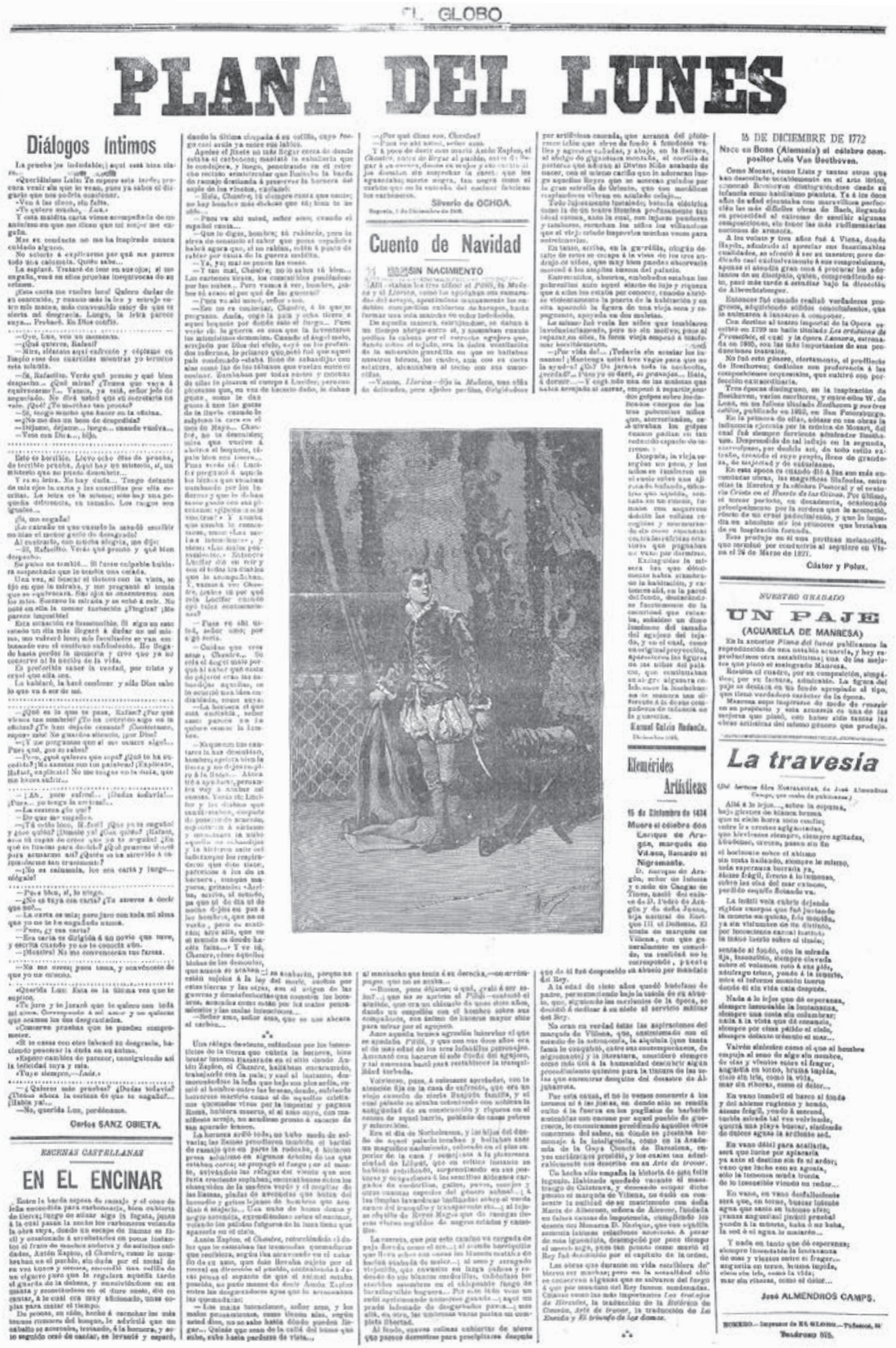

Último número de «Plana del Lunes», El Globo 26-12-1898 (BNE). 